\title{
INFLUENCE OF FOLIAR APPLICATION BY SALICYLIC ACID AND SOME MICRONUTRIENTS ON GROWTH, YIELD AND QUALITY OF ONION CROP
}

\author{
Geries, L.S.M. ${ }^{1}$, A.M.A. Abo Dahab ${ }^{1}$ and E.A. Abo-Marzoka ${ }^{2}$ \\ ${ }^{1}$ Onion Res. Dept., Field Crops Res. Inst., ARC, Egypt. \\ ${ }^{2}$ Dept. Of Crop Physiology, Field Crops Res. Inst., ARC, Egypt.
}

\begin{abstract}
Two field experiments were conducted at the Experimental Farm of Sakha Agricultural Research Station to study the effect of foliar application with salicylic acid with and without of some micronutrients ( $\mathrm{Fe}, \mathrm{Zn}$ and $\mathrm{Mn}$ ) as well as their interaction, on the growth, onion bulbs yield and its quality as well as storability of onion bulbs variety Giza Red during the two successive winter seasons of $2012 / 2013$ and $2013 / 2014$. Strip-plot design with four replications was used in this investigation. The horizontal plots were randomly assigned by the three foliar application with salicylic acid rates (100, 200 and $300 \mathrm{ppm})$, whereas foliar application with micronutrients at the same dose, $2 \mathrm{ml} \mathrm{L}$ (spraying with water; spraying with $\mathrm{Fe}$ or $\mathrm{Zn}$ or $\mathrm{Mn}$ and spraying with $\mathrm{Fe}+\mathrm{Zn}+$ $\mathrm{Mn}$ ) were randomly distributed in vertical plots. The obtained results could be summarized as follows:

- The maximum values of growth characteristics (No. of leaves/plant, bulb diameter $(\mathrm{cm})$, dry weight of onion plant and leaf area/plant), average bulb weight, culls bulb weight, marketable and total bulbs yield $\left(\mathrm{t} \mathrm{fed}^{-1}\right.$ ) were obtained under foliar application of salicylic acid at the rate of $200 \mathrm{ppm}$, while the lowest values were recorded under spraying salicylic acid at the rate of $100 \mathrm{ppm}$.

- Foliar application of onion plants with mixture of $\mathrm{Fe}, \mathrm{Zn}$ and $\mathrm{Mn}$ markedly increased bulb yield and its components with best growth characteristics followed by that sprayed with $\mathrm{Zn}$.

- Foliar application of salicylic acid at the rate of $200 \mathrm{ppm}$ and micronutrients ( $\mathrm{Fe}+\mathrm{Zn}+\mathrm{Mn}$, at the rate of $2 \mathrm{ml} \mathrm{L}^{-1}$ in combination) resulted in the tallest plants, the heaviest bulb weight, culls bulb weight, marketable and total bulbs yield (t fed. ${ }^{-1}$ ) and the highest leaf area/plant of onion compared with control treatment.

- After storing for 180 days the lowest values of weight loss \% was observed under combination of salicylic acid at $200 \mathrm{ppm}$ with mixture of $\mathrm{Fe}, \mathrm{Zn}$ and $\mathrm{Mn}$ which achieved the maximum values of remained bulbs\% in both seasons. Moreover, the obtained data revealed that, the highest nutritional values in onion bulb tissues were detected when mixture of the three nutrition elements ( $\mathrm{Fe}, \mathrm{Zn}$ and $\mathrm{Mn}$ ) together.

Generally, from the economic point of view, this study can be recommend that foliar application with salicylic acid for three times with the rate of $200 \mathrm{ppm}$ in each once as well as spraying with a mixture of micronutrients $\left(\mathrm{Fe}+\mathrm{Zn}+\mathrm{Mn}\right.$ at the rate of $\left.2 \mathrm{ml} \mathrm{L}^{-1}\right)$ to increase onion productivity and storability as well as quality improvement.
\end{abstract}

Key words: Salicylic acid, onion, micronutrients, foliar application, onion bulb yield. 


\section{INTRODUCTION}

Onion (Allium cepa L.) is one of the most important commercial vegetable crops and is widely grown in almost all over the world (Mishra et al., 2013). Onion has its own distinctive flavour and is used in soups, different dishes, salads, sandwiches and is also cooked alone as a vegetable. Its pungency is due to the presence of Allyl propyl disulphide, a volatile oil (Malik, 1994). It contains carbohydrates, protein, vitamin A, thiamine, riboflavin, niacin and ascorbic acid. The Egyptian onion is famous all over the world for its superior quality and early appearance in European markets. Onion although primarily is grown for food, it is also used as traditional medicine. The devoted area and production in Egypt for onion's production in 2014 is about 152539 fed. $^{-1 \ddagger}$ with an average of $15.04 \mathrm{t}$ of bulb fed..$^{-1}$

Salicylic acid (SA) recently included in the class of phytohormones for proper plant growth development and induction of tolerance to both biotic as well as abiotic stresses. In general, SA is an important defensive signal in plants that is essential for elicitor triggered immunity and the establishment of Systemic Acquired Resistance (SAR) (Carr et al., 2010). Thus, SA is an endogenous growth regulator with phenolic nature, which participates in regulation of several physiological processes in crop plants such as stomata closure, ion uptake, inhibition of ethylene biosynthesis and transpiration, seed germination, yield, glycolysis, flowering and heat production in thermo genic plants (Amin et al., 2007 and Khan et al., 2007). Ion uptake and transport (Thapa et al., 2005), the anti-oxidant capacity and phenolic content of tomato plants was increased at 10-4 $M$ salicylic acid treatment (Khan et al., 2007), a natural signal molecule, has been shown to play an important role in regulating a number of physiological processes in plants. Its exogenous application has promoted plant performance under biotic and abiotic stresses. It is now clear that salicylic acid provides protection against a number of abiotic stresses such as heat stress in mustard seedlings (Daka et al., 2011), chilling damage indifferent plants (Abd El-Samad et al., 2011). SA potentiated the generation of reactive oxygen species (ROS) in photosynthetic tissues of Arabidopsis during osmotic stress, thus participating in the development of stress symptoms. It has been shown that SA alleviates the adverse effect of salinity by increasing growth hormones such as IAA and cytokines (Lee, 2010 and Shama

\footnotetext{
\# Source: Agriculture Directorates of Governorates. Publisher: Economic Affairs Sector.
} 
et al., 2016), reducing the uptake and accumulation of toxic ions and maintaining the cellular membrane integrity (Shaheen et al., 2007). They stated, generally, that foliar application with salicylic acid at relatively low used concentrations promoted significantly plant growth characters of the investigated species; all, being in harmony with the present findings.

Micronutrient deficiency can greatly disturb plant yield and quality. The foliar application of micro-nutrients have very important role in improving onion, productivity and quality of onion bulbs. The foliar application has beneficial role in recovery of nutritional and physiological disorders in onion. Previous studies are indicative of a positive role of foliar nutrition in improved quality and quantity of onion bulbs (Abdissa et al., 2011; Ballabh et al., 2014 and Manna and Maity, 2016). Manna et al. (2014) have shown that application of $\mathrm{ZnSO}_{4}(0.5 \%)$ and $\mathrm{FeSO}_{4}(1.0 \%)$ as foliar spray recorded significantly higher plant height and other growth parameters as compared to other treatments in onion. They serve as an activator of many plant enzymes required in growth processes. Magnesium and Manganese are mobile within plants and can be readily translocate from older to younger tissues when it is deficient. Plants need $\mathrm{Fe}, \mathrm{Zn}$ and $\mathrm{Mn}$ to balance the generally high use of N, P and K from fertilizers (Kirkby and Römheld, 2004) on onion.

However, information on the use of micro nutrient in combination with salicylic acid for onion is scanty in Egypt. Therefore, an attempt was made to study the influence of foliar application of salicylic acid and Fe, $\mathrm{Zn}$ and $\mathrm{Mn}$ on onion cultivar Giza red, specially the change in quality properties and storability.

\section{MATERIALS AND METHODS}

\section{Experimental treatments}

Two field experiments were conducted at the Experimental Farm of Sakha Agricultural Research Station in Kafr El-Sheikh Governorate at North Nile Middle Delta region during the two successive seasons of 2012/2013 and 2013/2014 to study the response of onion plant to foliar application by $\mathrm{Fe}, \mathrm{Zn}$ and $\mathrm{Mn}$ as individually and/or mixed under the foliar application of salicylic acid. Some physical and chemical analyses of the experimental soil were listed in Table (1) in accordance to the methods of Page (1982). Onion seed were sown within the period of $10-17^{\text {th }}$ of October in 2012/2013 and 2013/2014 seasons. Onion seedlings cv. Giza Red were transplanted on December, $10^{\text {th }}$ and $19^{\text {th }}$ for $1^{\text {st }}$ and $2^{\text {nd }}$ seasons, respectively. At days after transplanting date, foliar spraying by $\mathrm{Fe}$ (Agro- Fe $10 \%$ ), Zn (Agro- Zn $10 \%$ ), and Mn (Agro-Mn 7\%) and 
where the three nutrition's elements are cheated by amino and organic acid (produced and distributed by the International Agrico-Company).

Table (1): Physical and chemical properties of the experimental soil sites

\begin{tabular}{|c|c|c|c|c|c|c|c|c|c|c|}
\hline \multicolumn{4}{|c|}{ Particle size } & \multirow{2}{*}{$\begin{array}{c}\begin{array}{c}\text { Soil } \\
\text { textural }\end{array} \\
\text { Clayey soil }\end{array}$} & \multirow{2}{*}{\multicolumn{2}{|c|}{$\begin{array}{c}\text { E.C. }(\mathrm{ds} / \mathrm{m}) \\
2.12\end{array}$}} & \multirow{2}{*}{$\begin{array}{l}\text { Soil pH } \\
(1: 2.5) \\
7.82\end{array}$} & \multirow{2}{*}{\multicolumn{2}{|c|}{$\begin{array}{c}\text { Organic matter } \\
(\%) \\
1.52\end{array}$}} & \multirow{2}{*}{$\begin{array}{c}\mathrm{CaCO} 3(\%) \\
3.08\end{array}$} \\
\hline $\begin{array}{c}\text { Sand \% } \\
17.64\end{array}$ & & & $\begin{array}{c}\text { Clay \% } \\
48.84 \\
\end{array}$ & & & & & & & \\
\hline \multicolumn{4}{|c|}{ Soluble Cations (meq/L) } & \multicolumn{4}{|c|}{ Soluble anions(meq/L) } & \multicolumn{3}{|c|}{ available contents (ppm) } \\
\hline $\begin{array}{c}\mathrm{Ca}++ \\
5.8\end{array}$ & $\begin{array}{l}\mathrm{Mg++} \\
3.4\end{array}$ & $\begin{array}{l}\mathrm{Na}+ \\
11.5\end{array}$ & $\begin{array}{c}\mathrm{K}+ \\
0.58\end{array}$ & $\begin{array}{l}\text { CO3-- } \\
0.10\end{array}$ & $\begin{array}{l}\mathrm{HCO}- \\
3.46\end{array}$ & $\begin{array}{c}\mathrm{Cl}- \\
4.30\end{array}$ & $\begin{array}{l}\text { so4-- } \\
13.52\end{array}$ & $\begin{array}{c}\mathrm{N} \\
27.8\end{array}$ & & $\begin{array}{c}\mathrm{K} \\
396\end{array}$ \\
\hline
\end{tabular}

During soil preparation, all phosphorus requirement fertilizer was added at the rate of $60 \mathrm{P}_{2} \mathrm{O}_{5} \mathrm{~kg}$ fed. ${ }^{-1}$ mixed with potassium sulphate $(48 \%)$ requirement at the rate of $50 \mathrm{~K}_{2} \mathrm{O}$ unites fed. ${ }^{-1}$. The nitrogen fertilizer at rate of $120 \mathrm{~kg} \mathrm{fed}^{-1}$ as ammonium nitrate (33.5\%) was side dressed at two equal doses, at 30 days old, the $1^{\text {st }}$ half of nitrogen, whereas the $2^{\text {nd }}$ half $\mathrm{N}$ dose was applied at 60 days old. During the two experimental seasons, spraying of salicylic acid and some micronutrients ( $\mathrm{Fe}, \mathrm{Mn}$ and $\mathrm{Zn}$ ) was conducted three times as individual and/or as mixed; first one 50 days after transplanting and then every 15 days for the second and third spraying. The experiment design was a strip-plot design with four replicates. The horizontal plots were randomly assigned by the three foliar application with salicylic acid rates, whereas foliar application with micronutrients were randomly distributed in vertical plots. The experimental plot area was $8.4 \mathrm{~m}^{2}$ (included 4 ridges, $60 \mathrm{~cm}$ width and 3.5 meter long). All the cultural operations like nursery raising, main field preparation, transplanting, fertilization, irrigation; weeding, plant protection etc. were carried out as per the recommendations in order to raise a successful crop. So, this investigates include the following treatments:

Horizontal plots: Foliar application of salicylic acid:

$\mathrm{a}_{1}$ ) Foliar application with $100 \mathrm{ppm}$.

$\mathrm{a}_{2}$ ) Foliar application with $200 \mathrm{ppm}$.

$a_{3}$ ) Foliar application with 300 ppm.

Vertical plots: Foliar application (micronutrients treatments):

$b_{1}$ ) Control (spraying with water).

$\left.\mathrm{b}_{2}\right)$ Foliar application with $\mathrm{Fe}\left(2 \mathrm{ml} \mathrm{L}^{-1}\right)$.

$\mathrm{b}_{3}$ ) Foliar application with $\mathrm{Zn}\left(2 \mathrm{ml} \mathrm{L}^{-1}\right)$.

$\mathrm{b}_{4}$ ) Foliar application with $\mathrm{Mn}\left(2 \mathrm{ml} \mathrm{L}^{-1}\right)$.

$\left.\mathrm{b}_{5}\right)$ Foliar application with $\mathrm{Fe}+\mathrm{Zn}+\mathrm{Mn}\left(2 \mathrm{ml} \mathrm{L}^{-1}\right)$.

1. Growth characteristics: a representative samples, each five plants were randomly taken from the $2^{\text {nd }}$ row of each plot at 90,110 
and 130 DAT (days after transplanting) to estimating following data:

1.a. Vegetative plant growth: plant height $(\mathrm{cm})$, No. of leaves/plant, bulb diameter $(\mathrm{cm})$ and dry weight of onion plant (g/plant). Leaf area/plant was recorded by using following formula: leaf area $\left(\mathrm{cm}^{2}\right.$ (plant $)=0.000199+1.277 \times$ leaf length $\times$ leaf diameter at a distance of $25 \%$ from the leaf base $\times$ No. of leaves (Corcoles et al., 2015).

1.b. Determination of photosynthetic pigments in leaves: The total chlorophyll pigments $\left(\mathrm{mg} \mathrm{dm}^{-2}\right)$ were determined according to Wettesteien (1957).

2. Bulb yield and its physical properties: At harvest time the total weights of bulbs resulting from each experimental plot were recorded and culls bulb weight $\left(\mathrm{t} \mathrm{fed}^{-1}\right)$, marketable bulbs yield $\left(\mathrm{t}\right.$ fed. $\left.{ }^{-1}\right)$ and total bulbs yield $\left(\mathrm{t} \mathrm{fed}^{-1}\right)$ were estimated. Samples of 5 bulbs from each plot were randomly selected to determine average weight $(\mathrm{g})$ and diameter of bulb $(\mathrm{cm})$.

3- Nutritional value of bulb tissues: In oven dry bulb tissues $N, P$ and $\mathrm{K}$ were determined according to the methods described by Pregl (1945), Troug and Mayer (1939) and Brown and Lilleland (1946) for N, P and K, respectively. However, Fe, Zn and $\mathrm{Mn}$ uptake were determined using flame ionization atomic absorption spectrometer model 1100 B (Perkin Elemer) according the method of Chapman and Pratt (1978).

4- Cumulative weight loss of onion bulb during storage: The storability was observed after harvest of onion bulb at different days after storage. Weight loss and remained bulbs\% of onion was estimated after 60,120 and 180 days of storage according to the formula of Wills et al. (1982) as follow:

$$
\text { Weight loss } \%=\frac{\text { Weight loss of bulb }}{\text { Total bulb weight at beginning of storage }} \times 100
$$

Remainder bulb $\%=1$ - final weight loss $\%$.

5. Economic analysis: Economic analysis was performed to calculate gross return, net return and the benefit cost ratio with respect to each treatment.

5.a. Gross returns: Economic yield of onion (onion bulbs) was converted into gross return (L.E. fed. ${ }^{-1}$ ) on the basis of local market price.

5.b. Net return: It was calculated by subtracting the cost of cultivation from the gross return.

5.c. Benefit cost ratio: It was calculated by the following formula, B: $C$ ratio $=$ Gross return/Cost of cultivation . 
Statistical analysis: All obtained data were subjected to the statistical analysis and means were compared according to LSD at $5 \%$ level test as described by Gomez and Gomez (1984).

\section{Growth characteristics:}

\section{RESULTS AND DISCUSSION}

\section{1.a. Vegetative plant growth:}

Onion plant growth characters as expressed by plant height, blub diameter, No. of leaves/plant and dry weight of whole plant as well as leaf area/plant as affected by foliar spraying with SA and micronutrients are presented in Tables (2, 3, 4 and 5) for the two experimental seasons. The highest values of onion plant growth parameters were recorded from plants, which received salicylic acid at 200 ppm, whereas the statistical analysis of the obtained data indicated that the differences within the three foliar spraying of salicylic acid were great enough to reach the $5 \%$ level of significant. These findings were true in both experiments for all plant growth measurements.

Table (2): Effect of salicylic acid, micronutrients treatments and their interaction on plant height $(\mathrm{cm})$ at 90,110 and 130 DAT in 2012/2013 and $2013 / 2014$ seasons

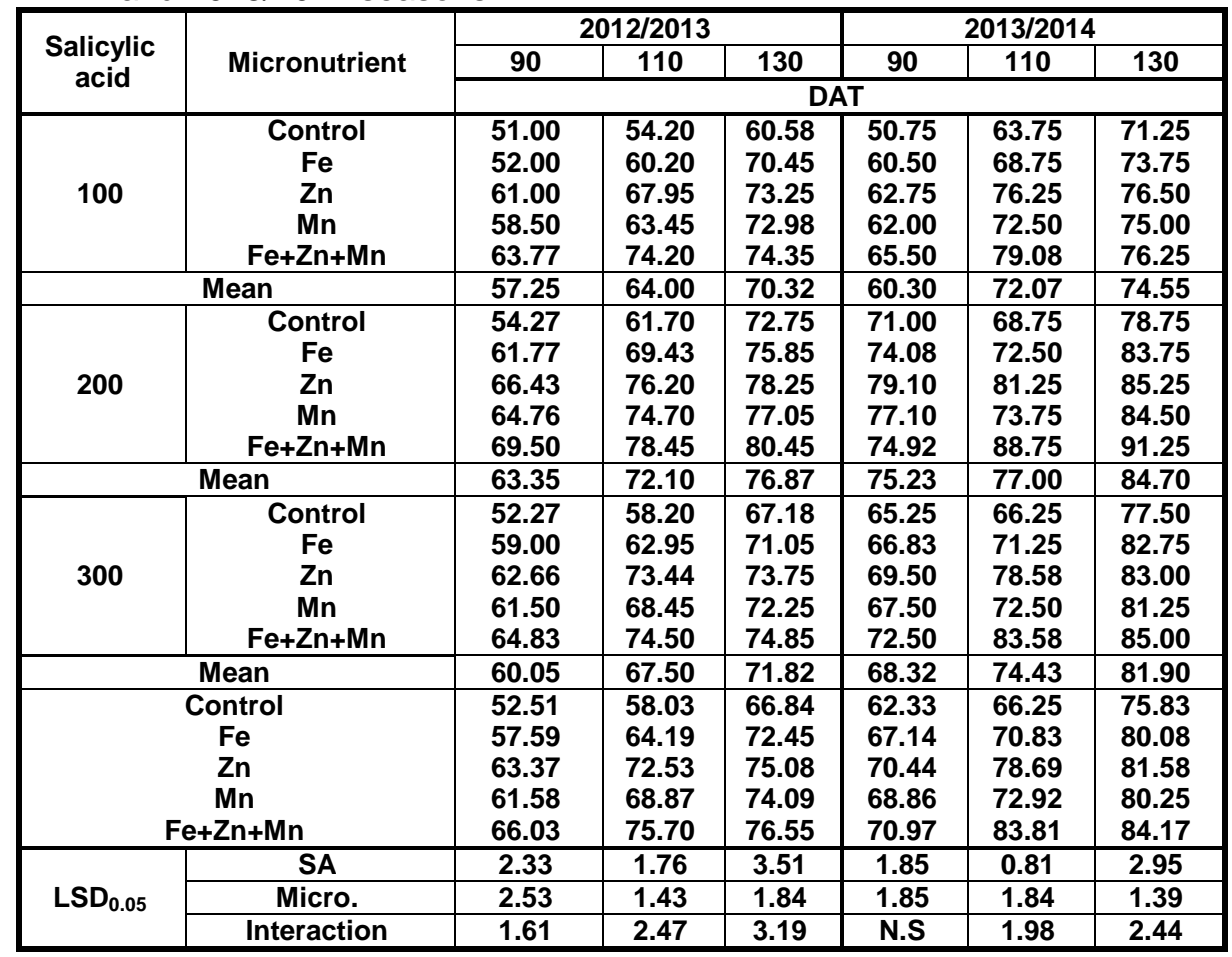


N.S indicate not significant at $P: 0.05$.

Table (3): Number of leaves/plant and bulb diameter as influenced by salicylic acid, micronutrients and their interaction at 90, 110 and 130 DAT in $2012 / 2013$ and $2013 / 2014$ seasons

\begin{tabular}{|c|c|c|c|c|c|c|c|c|c|c|c|c|c|}
\hline \multirow{4}{*}{$\begin{array}{c}\text { Salicylic } \\
\text { acid }\end{array}$} & \multirow{4}{*}{ Micronutrient } & \multicolumn{6}{|c|}{$2012 / 2013$} & \multicolumn{6}{|c|}{$2012 / 2014$} \\
\hline & & \multicolumn{3}{|c|}{$\begin{array}{c}\text { No. of } \\
\text { leaves/plant }\end{array}$} & \multicolumn{3}{|c|}{$\begin{array}{l}\text { Bulb diameter } \\
\text { (cm) }\end{array}$} & \multicolumn{3}{|c|}{$\begin{array}{c}\text { No. of } \\
\text { leaves/plant }\end{array}$} & \multicolumn{3}{|c|}{$\begin{array}{c}\text { Bulb diameter } \\
\text { (cm) }\end{array}$} \\
\hline & & \multicolumn{12}{|c|}{ DAT } \\
\hline & & 90 & 110 & 130 & 90 & 110 & 130 & 90 & 110 & 130 & 90 & 110 & 130 \\
\hline \multirow{5}{*}{100} & Control & 4.23 & 6.10 & 5.13 & 2.30 & 2.80 & 3.53 & 4.80 & 6.40 & 5.07 & 1.55 & 1.73 & 2.19 \\
\hline & $\mathrm{Fe}$ & 5.57 & 6.27 & 6.17 & 2.40 & 3.40 & 3.80 & 5.47 & 6.53 & 5.57 & 1.94 & 2.09 & 2.53 \\
\hline & $\mathrm{Zn}$ & 6.43 & 7.50 & 7.17 & 3.03 & 3.95 & 4.38 & 5.73 & 6.87 & 5.90 & 2.16 & 3.81 & 4.03 \\
\hline & Mn & 5.90 & 6.82 & 6.43 & 2.50 & 3.73 & 4.13 & 5.73 & 6.73 & 5.80 & 2.05 & 3.01 & 3.71 \\
\hline & $\mathrm{Fe}+\mathrm{Zn}+\mathrm{Mn}$ & 7.13 & 8.23 & 7.73 & 3.59 & 4.15 & 4.85 & 6.27 & 7.27 & 6.40 & 2.25 & 3.95 & 4.24 \\
\hline \multicolumn{2}{|c|}{ Mean } & 5.85 & 6.98 & 6.53 & 2.76 & 3.61 & 4.14 & 5.60 & 6.76 & 5.75 & 1.99 & 2.92 & 3.34 \\
\hline \multirow{5}{*}{200} & Control & 5.27 & 6.57 & 6.00 & 2.60 & 3.64 & 4.37 & 5.90 & 6.97 & 6.80 & 3.20 & 3.36 & 4.01 \\
\hline & $\mathrm{Fe}$ & 5.97 & 6.60 & 6.50 & 3.20 & 5.40 & 5.59 & 6.60 & 7.33 & 7.03 & 3.28 & 3.51 & 5.17 \\
\hline & $\mathrm{Zn}$ & 7.10 & 7.80 & 7.77 & 4.90 & 5.43 & 6.00 & 7.18 & 7.58 & 7.37 & 3.61 & 4.09 & 5.62 \\
\hline & Mn & 6.33 & 7.50 & 6.83 & 4.50 & 5.60 & 5.97 & 6.83 & 7.48 & 7.21 & 3.73 & 3.99 & 5.48 \\
\hline & $\mathrm{Fe}+\mathrm{Zn}+\mathrm{Mn}$ & 7.87 & 9.27 & 8.20 & 5.15 & 5.93 & 6.63 & 7.66 & 8.37 & 7.87 & 4.14 & 4.21 & 5.89 \\
\hline \multicolumn{2}{|c|}{ Mean } & 6.51 & 7.55 & 7.06 & 4.07 & 5.20 & 5.71 & 6.84 & 7.55 & 7.26 & 3.59 & 3.83 & 5.23 \\
\hline \multirow{5}{*}{300} & Control & 4.35 & 6.20 & 5.33 & 2.90 & 3.17 & 3.47 & 5.39 & 6.50 & 6.11 & 2.25 & 2.51 & 2.75 \\
\hline & $\mathrm{Fe}$ & 5.60 & 6.37 & 6.43 & 3.40 & 4.37 & 4.63 & 6.23 & 6.67 & 6.47 & 2.38 & 3.92 & 4.24 \\
\hline & $\mathrm{Zn}$ & 6.90 & 7.67 & 7.27 & 4.10 & 4.66 & 5.03 & 6.67 & 7.45 & 6.93 & 2.90 & 4.12 & 4.71 \\
\hline & Mn & 6.27 & 7.20 & 6.73 & 3.78 & 4.46 & 4.77 & 6.43 & 7.07 & 6.50 & 2.69 & 3.93 & 4.24 \\
\hline & $\mathrm{Fe}+\mathrm{Zn}+\mathrm{Mn}$ & 7.63 & 8.47 & 8.03 & 4.40 & 5.78 & 6.09 & 7.07 & 8.30 & 7.03 & 3.08 & 4.20 & 4.88 \\
\hline \multicolumn{2}{|c|}{ Mean } & 6.15 & 7.18 & 6.76 & 3.72 & 4.49 & 4.80 & 6.35 & 7.19 & 6.61 & 2.66 & 3.73 & 4.16 \\
\hline \multicolumn{2}{|c|}{ Control } & 4.62 & 6.28 & 5.48 & 2.60 & 3.20 & 3.79 & 5.36 & 6.62 & 5.99 & 2.33 & 2.54 & 2.99 \\
\hline \multicolumn{2}{|r|}{$\mathrm{Fe}$} & 5.71 & 6.41 & 6.37 & 3.00 & 4.39 & 4.68 & 6.10 & 6.84 & 6.36 & 2.53 & 3.17 & 3.98 \\
\hline \multicolumn{2}{|r|}{$\mathrm{Zn}$} & 6.81 & 7.66 & 7.40 & 4.01 & 4.68 & 5.14 & 6.53 & 7.30 & 6.73 & 2.89 & 4.01 & 4.78 \\
\hline \multicolumn{2}{|r|}{ Mn } & 6.17 & 7.17 & 6.67 & 3.59 & 4.60 & 4.96 & 6.33 & 7.09 & 6.50 & 2.82 & 3.64 & 4.49 \\
\hline \multicolumn{2}{|c|}{$\mathrm{Fe}+\mathrm{Zn}+\mathrm{Mn}$} & 7.54 & 8.65 & 7.99 & 4.38 & 5.28 & 5.86 & 7.00 & 7.98 & 7.10 & 3.16 & 4.12 & 5.00 \\
\hline \multirow{3}{*}{$\operatorname{LSD}_{0.05}$} & SA & 0.46 & 0.22 & 0.23 & 0.16 & 0.28 & 0.14 & 0.49 & 0.13 & 0.30 & 0.90 & 0.38 & 0.41 \\
\hline & Micro. & 0.43 & 0.21 & 0.36 & 0.24 & 0.28 & 0.24 & 0.26 & 0.22 & 0.31 & 0.27 & 0.28 & 0.31 \\
\hline & Interaction & N.S & N.S & N.S & 0.57 & N.S & N.S & N.S & 0.38 & N.S & N.S & 0.54 & 0.29 \\
\hline
\end{tabular}

N.S indicate not significant at $P: 0.05$.

Our results are in agreement with those of Dake et al. (2011) who showing that salicylic acid stimulate both cell division and cell 
elongation. In the same respect, plants treated with salicylic acid revealed higher enzymatic activity. Results indicated a positive influence of SA on leaf area, which was in agreement with Aisha et al., 2007; Amin et al., 2007; Khan et al., 2007; Pradhan et al., 2016; Prajapati et al., 2016 and Shama et al., 2016. It is suggested that because SA has anti-senescence influence on plant organs, vegetative growth may be prolonged following its application consequently leading to higher leaf area.

Data of Tables (2, 3, 4 and 5) clearly showed that, onion plants which received $\mathrm{Fe}, \mathrm{Zn}$ and $\mathrm{Mn}$ as individually and/or mixed as a simple combination within each three elements $(\mathrm{Fe}+\mathrm{Zn}+\mathrm{Mn})$ were recorded an enhancement in all plant growth measurements comparison with untreated foliar application of micronutrients. Moreover, the obtained data reveals that, when the three studied elements were mixed together and sprayed as foliar gained the best plant growth criteria's if compound with the other treatments. These findings are in good accordance (Acharya et al. 2015a, b). Generally, it could be concluded that, the application of $\mathrm{Fe}, \mathrm{Zn}$ and $\mathrm{Mn}$ as mixture gave superiority in growth of onion plant, followed by application each element as individually. Many other investigators detected that, plant growth as expressed by plant height $(\mathrm{cm})$, bulb diameter $(\mathrm{cm})$, No. of leaves/plant, dry weight of onion plant ( $\mathrm{g} /$ plant) and leaf area/plant $\left(\mathrm{cm}^{2}\right)$ are positive associated with foliar spraying of micronutrients (Shaheen et al., 2007; Shaheen et al., 2012; Ballabh et al., 2014; Haque et al., 2014; Manna et al., 2014; Acharya et al., 2015 a\&b and Manna and Maity, 2016).

The statistical analysis of the collected data showed that, the interaction effect of salicylic acid and micronutrients on plant height, bulb diameter, No. of leaves, leaf area/plant and dry weight of onion plant were significant at 90, 110 and 130 DAT in most cases. Results showed that maximum plant height, No. of leaves/plant, bulb diameter, leaf area/plant and plant dry weight were observed from the treatment combination of SA at $200 \mathrm{ppm}$ with the mixture of $\mathrm{Fe}, \mathrm{Zn}$ and $\mathrm{Mn}$ followed by that sprayed with $\mathrm{Zn}$, while the minimum values of onion plant growth characters were recorded from combination of SA at 100 ppm with foliar spraying of water (control). 
Table (4): Effect of salicylic acid and micronutrients treatment and their interaction on leaf area/plant $\left(\mathrm{cm}^{2}\right)$ of onion at 90, 110 and 130 DAT in $2012 / 2013$ and $2013 / 2014$ seasons

\begin{tabular}{|c|c|c|c|c|c|c|c|}
\hline \multirow{4}{*}{ Salicylic acid } & \multirow{4}{*}{ Micronutrient } & \multicolumn{3}{|c|}{$2012 \backslash 2013$} & \multicolumn{3}{|c|}{$2013 \backslash 2014$} \\
\hline & & \multicolumn{6}{|c|}{ Leaf area/plant $\left(\mathrm{cm}^{2}\right)$} \\
\hline & & 90 & 110 & 130 & 90 & 110 & 130 \\
\hline & & \multicolumn{6}{|c|}{ DAT } \\
\hline \multirow{5}{*}{100} & Control & 507.39 & 677.60 & 910.94 & 339.14 & 569.47 & 883.18 \\
\hline & $\mathrm{Fe}$ & 547.47 & 884.53 & 1201.41 & 366.29 & 631.84 & 974.65 \\
\hline & $\mathrm{Zn}$ & 578.21 & 913.67 & 1451.28 & 405.54 & 661.77 & 1013.73 \\
\hline & Mn & 548.66 & 908.04 & 1271.13 & 397.09 & 656.84 & 974.98 \\
\hline & $\mathrm{Fe}+\mathrm{Zn}+\mathrm{Mn}$ & 594.25 & 1008.50 & 1560.91 & 422.95 & 729.66 & 1164.81 \\
\hline \multicolumn{2}{|c|}{ Mean } & 555.19 & 878.47 & 1279.13 & 386.20 & 649.92 & 1002.27 \\
\hline \multirow{5}{*}{200} & Control & 555.53 & 781.55 & 973.93 & 540.00 & 980.73 & 1353.29 \\
\hline & $\mathrm{Fe}$ & 591.87 & 1013.03 & 1368.18 & 582.92 & 1062.93 & 1532.45 \\
\hline & Zn & 624.80 & 1359.80 & 2037.52 & 681.41 & 1287.31 & 1938.66 \\
\hline & Mn & 624.79 & 1247.04 & 1803.37 & 596.34 & 1212.82 & 1857.40 \\
\hline & $\mathrm{Fe}+\mathrm{Zn}+\mathrm{Mn}$ & 673.23 & 1681.45 & 2686.21 & 744.53 & 1531.11 & 2481.78 \\
\hline \multicolumn{2}{|c|}{ Mean } & 614.04 & 1216.57 & 1773.83 & 629.04 & 1214.98 & 1832.72 \\
\hline \multirow{5}{*}{300} & Control & 521.83 & 739.40 & 935.49 & 434.30 & 672.11 & 906.08 \\
\hline & $\mathrm{Fe}$ & 552.81 & 853.69 & 1153.84 & 458.64 & 740.81 & 1074.12 \\
\hline & Zn & 620.13 & 954.01 & 1277.80 & 502.82 & 778.32 & 1151.34 \\
\hline & Mn & 595.43 & 931.04 & 1248.37 & 485.56 & 735.90 & 1038.59 \\
\hline & $\mathrm{Fe}+\mathrm{Zn}+\mathrm{Mn}$ & 657.53 & 1071.58 & 1433.08 & 531.98 & 894.31 & 1380.39 \\
\hline \multicolumn{2}{|c|}{ Mean } & 589.55 & 909.94 & 1209.71 & 482.66 & 764.29 & 1110.10 \\
\hline \multicolumn{2}{|c|}{ Control } & 528.25 & 732.85 & 940.12 & 437.81 & 740.77 & 1047.52 \\
\hline \multicolumn{2}{|c|}{$\mathrm{Fe}$} & 564.05 & 917.08 & 1241.14 & 469.28 & 811.86 & 1193.74 \\
\hline \multicolumn{2}{|c|}{ Zn } & 607.72 & 1075.83 & 1588.78 & 529.92 & 909.13 & 1367.91 \\
\hline \multicolumn{2}{|c|}{ Mn } & 589.63 & 1028.71 & 1440.96 & 493.00 & 868.52 & 1290.32 \\
\hline \multicolumn{2}{|c|}{$\mathrm{Fe}+\mathrm{Zn}+\mathrm{Mn}$} & 641.67 & 1253.85 & 1893.40 & 566.48 & 1051.69 & 1675.66 \\
\hline \multirow{3}{*}{$\operatorname{LSD}_{0.05}$} & SA & 16.93 & 24.818 & 11.129 & 22.583 & 24.764 & 10.70 \\
\hline & Micro. & 24.03 & 26.795 & 19.815 & 8.417 & 13.453 & 10.175 \\
\hline & Interaction. & 41.62 & 46.409 & 34.321 & 14.578 & 6.181 & 17.624 \\
\hline
\end{tabular}

\section{1.b. Determination of photosynthetic pigments in leaves:}

Effect of salicylic acid and micronutrients on chlorophyll a, chlorophyll b and total chlorophyll at 90,110 and 130 days from transplanting are presented in Tables (6 and 7). The data showed that chlorophyll $\mathrm{a}$, chlorophyll $\mathrm{b}$ and total chlorophyll were significantly increased with increasing the applied concentration of SA up to 200 ppm. These results are in agreement with those results obtained by Amin et al., 2007 and Haggag and Saber, 2007. They found that SA at $200 \mathrm{ppm}$ gave the highest chlorophyll a, chlorophyll $b$ and total chlorophyll content due to the stimulatory effect on the amount of metabolites synthesized through enhancement of cell division and chlorophyll accumulation, which led to higher rate of photosynthesis. 
While, salicylic acid at relatively low dose (100 ppm) caused a significant decrease in chlorophyll contents. The improving of plant growth under spraying with salicylic acid at $200 \mathrm{ppm}$ may be due to the role of these materials on enhancing cell division activity, increasing of proline accumulation of plant and increasing of endogenous phytohormones i.e. increasing promotion hormones (IAA, $\mathrm{GA}_{3}$ and cytokinins) and reducing ABA content (Gamelli and Hadi, 2000) which found that bio-regulators make a shift in hormonal balance characterized by increasing in endogenous phytohormon in plant. In conclusion, high chlorophyll content of SA-treated plants may be responsible for the improved fresh and dry matter accumulation and also final bulb yield. These results are in a great harmony with those results obtained by Amin et al., 2007; Pradhan et al., 2016 and Shama et al., 2016.

Table (5): Effect of salicylic acid, micronutrients treatment and their interaction on dry weight of onion plant (g/plant) at 90, 110 and 130 DAT in 2012/2013and 2013/2014 seasons

\begin{tabular}{|c|c|c|c|c|c|c|c|}
\hline \multirow{4}{*}{ Salicylic acid } & \multirow{4}{*}{ Micronutrient } & \multicolumn{3}{|c|}{201212013} & \multicolumn{3}{|c|}{$2013 \backslash 2014$} \\
\hline & & \multicolumn{6}{|c|}{ Dry weight (g/plant) } \\
\hline & & 90 & 110 & 130 & 90 & 110 & 130 \\
\hline & & \multicolumn{6}{|c|}{ DAT } \\
\hline 100 & Control & 7.64 & 14.98 & 31.40 & 7.30 & 17.06 & 26.44 \\
\hline \multicolumn{2}{|c|}{ Mean } & 8.31 & 18.60 & 35.89 & 9.79 & 19.96 & 31.13 \\
\hline 200 & Control & 10.92 & 23.30 & 43.52 & 10.58 & 22.66 & 39.06 \\
\hline \multicolumn{2}{|c|}{ Mean } & 12.67 & 26.20 & 47.64 & 14.25 & 27.51 & 44.82 \\
\hline 300 & Control & 8.81 & 19.40 & 36.44 & 11.44 & 20.64 & 33.91 \\
\hline \multicolumn{2}{|c|}{ Mean } & 10.99 & 23.04 & 41.08 & 13.30 & 25.08 & 39.62 \\
\hline \multicolumn{2}{|c|}{ Control } & 9.12 & 19.23 & 37.12 & 9.77 & 20.12 & 33.14 \\
\hline \multirow{3}{*}{ LSD $_{0.05}$} & SA & 0.74 & 0.47 & 0.90 & 0.55 & 1.15 & 2.11 \\
\hline & Micro. & 0.68 & 0.45 & 0.50 & 0.54 & 0.71 & 0.95 \\
\hline & Interaction. & N.S & 0.78 & 1.55 & 1.29 & 1.67 & 1.65 \\
\hline
\end{tabular}

N.S indicate not significant at P: 0.05 .

Foliar application of $\mathrm{Fe}, \mathrm{Zn}$ or $\mathrm{Mn}$ as mixture, gained superiority in chlorophyll $\mathrm{a}, \mathrm{b}$ and total chlorophyll of compared with the application as individual elements. Finally, it could be stated that, the best results of studied elements were detected when it mixed together followed by that, sprayed with $\mathrm{Zn}$ and applied each element as individually. According to Kirkby and Römheld (2004) and Haque et al. (2014), the foliar spraying of micronutrients for plant one fundamental for growth and development, acting as constituents of cell wall and members, as constituents of enzymes of activation of enzyme and photosynthesis. 
Table (6): Effect of salicylic acid, micronutrients treatment and their interaction on chlorophyll (a), chlorophyll (b) and total chlorophyll (mg $\mathrm{dm}^{-2}$ ) of onion in 2012/2013 season

\begin{tabular}{|c|c|c|c|c|c|c|c|c|c|c|}
\hline \multirow{4}{*}{$\begin{array}{c}\text { Salicylic } \\
\text { acid }\end{array}$} & \multirow{4}{*}{ Micronutrient } & \multicolumn{3}{|c|}{ Chlorophyll (a) } & \multicolumn{3}{|c|}{ Chlorophyll (b) } & \multicolumn{3}{|c|}{ Total chlorophyll } \\
\hline & & \multicolumn{9}{|c|}{$\mathrm{mg} \mathrm{dm}{ }^{-2}$} \\
\hline & & 90 & 110 & 130 & 90 & 110 & 130 & 90 & 110 & 130 \\
\hline & & \multicolumn{9}{|c|}{ DAT } \\
\hline \multirow{5}{*}{100} & Control & 1.29 & 1.36 & 1.31 & 0.46 & 0.62 & 0.99 & 1.83 & 1.91 & 2.29 \\
\hline & $\mathrm{Fe}$ & 1.31 & 1.37 & 1.42 & 0.52 & 0.70 & 1.04 & 1.88 & 2.01 & 2.46 \\
\hline & Zn & 1.32 & 1.40 & 1.44 & 0.53 & 0.78 & 1.09 & 1.93 & 2.10 & 2.53 \\
\hline & Mn & 1.31 & 1.40 & 1.43 & 0.53 & 0.76 & 1.06 & 1.92 & 2.07 & 2.49 \\
\hline & $\mathrm{Fe}+\mathrm{Zn}+\mathrm{Mn}$ & 1.35 & 1.43 & 1.48 & 0.55 & 0.82 & 1.20 & 1.97 & 2.17 & 2.68 \\
\hline \multicolumn{2}{|c|}{ Mean } & 1.32 & 1.39 & 1.42 & 0.52 & 0.73 & 1.08 & 1.91 & 2.05 & 2.49 \\
\hline \multirow{5}{*}{200} & Control & 1.40 & 1.51 & 1.56 & 0.49 & 0.83 & 1.19 & 1.89 & 2.34 & 2.75 \\
\hline & $\mathrm{Fe}$ & 1.41 & 1.55 & 1.63 & 0.57 & 0.92 & 1.24 & 1.99 & 2.47 & 2.87 \\
\hline & Zn & 1.46 & 1.57 & 1.69 & 0.59 & 0.98 & 1.30 & 2.05 & 2.55 & 2.99 \\
\hline & Mn & 1.43 & 1.58 & 1.65 & 0.59 & 0.93 & 1.29 & 2.02 & 2.51 & 2.94 \\
\hline & $\mathrm{Fe}+\mathrm{Zn}+\mathrm{Mn}$ & 1.49 & 1.60 & 1.72 & 0.61 & 1.01 & 1.46 & 2.09 & 2.61 & 3.18 \\
\hline \multicolumn{2}{|c|}{ Mean } & 1.44 & 1.56 & 1.65 & 0.57 & 0.93 & 1.30 & 2.01 & 2.50 & 2.95 \\
\hline \multirow{5}{*}{300} & Control & 1.30 & 1.39 & 1.45 & 0.53 & 0.70 & 1.10 & 1.82 & 2.09 & 2.55 \\
\hline & $\mathrm{Fe}$ & 1.43 & 1.45 & 1.52 & 0.54 & 0.86 & 1.13 & 1.96 & 2.30 & 2.65 \\
\hline & $\mathrm{Zn}$ & 1.43 & 1.48 & 1.58 & 0.56 & 0.90 & 1.19 & 1.99 & 2.37 & 2.77 \\
\hline & Mn & 1.43 & 1.48 & 1.53 & 0.55 & 0.90 & 1.17 & 1.98 & 2.38 & 2.71 \\
\hline & $\mathrm{Fe}+\mathrm{Zn}+\mathrm{Mn}$ & 1.44 & 1.49 & 1.60 & 0.58 & 0.94 & 1.34 & 2.03 & 2.43 & 2.95 \\
\hline \multicolumn{2}{|c|}{ Mean } & 1.41 & 1.46 & 1.54 & 0.55 & 0.86 & 1.19 & 1.96 & 2.31 & 2.73 \\
\hline \multicolumn{2}{|c|}{ Control } & 1.33 & 1.42 & 1.44 & 0.49 & 0.72 & 1.09 & 1.85 & 2.11 & 2.53 \\
\hline \multicolumn{2}{|r|}{$\mathrm{Fe}$} & 1.38 & 1.46 & 1.52 & 0.54 & 0.83 & 1.14 & 1.94 & 2.26 & 2.66 \\
\hline \multicolumn{2}{|r|}{$\mathrm{Zn}$} & 1.40 & 1.48 & 1.57 & 0.56 & 0.89 & 1.19 & 1.99 & 2.34 & 2.76 \\
\hline \multicolumn{2}{|c|}{ Mn } & 1.39 & 1.49 & 1.54 & 0.56 & 0.86 & 1.17 & 1.97 & 2.32 & 2.71 \\
\hline \multicolumn{2}{|c|}{$\mathrm{Fe}+\mathrm{Zn}+\mathrm{Mn}$} & 1.43 & 1.51 & 1.60 & 0.58 & 0.92 & 1.33 & 2.03 & 2.40 & 2.94 \\
\hline \multirow{3}{*}{ LSD $_{0.05}$} & SA & 0.04 & 0.03 & 0.01 & 0.01 & 0.02 & 0.004 & 0.03 & 0.02 & 0.01 \\
\hline & Micro. & 0.04 & 0.02 & 0.01 & 0.04 & 0.03 & 0.006 & 0.05 & 0.04 & 0.01 \\
\hline & Interaction. & N.S & N.S & 0.002 & N.S & N.S & 0.002 & N.S & N.S & 0.002 \\
\hline
\end{tabular}

N.S indicate not significant at P: 0.05 .

Concerning combination effect, all used combinations resulted in a slightly increase in chlorophyll a, b and total chlorophyll in compared with untreated plant in the most cases. Also, the combinations between salicylic acid at $200 \mathrm{ppm}$ and mixture from ( $\mathrm{Fe}$, $\mathrm{Zn}$ and $\mathrm{Mn}$ ) showed higher content of pigments at 90,110 and 130 
days from transplanting (data in Tables 6 and 7). Similar results were reported by Acharya et al. (2015 a, b).

Table (7): Chlorophyll (a), chlorophyll (b) and total chlorophyll ( $\mathrm{mg} \mathrm{dm}^{-2}$ ) of onion as affected by salicylic acid, micronutrients treatment and their interaction in 2013/2014 season

\begin{tabular}{|c|c|c|c|c|c|c|c|c|c|c|}
\hline \multirow{4}{*}{$\begin{array}{l}\text { Salicylic } \\
\text { acid }\end{array}$} & \multirow{4}{*}{ Micronutrient } & Chl & rophy & (a) & Chl & rophy & (b) & Tota & chlorc & ohyll \\
\hline & & \multicolumn{9}{|c|}{$\mathrm{mg} \mathrm{dm}^{-2}$} \\
\hline & & 90 & 110 & 130 & 90 & 110 & 130 & 90 & 110 & 130 \\
\hline & & \multicolumn{9}{|c|}{ DAT } \\
\hline \multirow{5}{*}{100} & Control & 1.02 & 1.11 & 1.13 & 0.62 & 0.66 & 0.80 & 1.64 & 1.77 & 1.93 \\
\hline & $\mathrm{Fe}$ & 1.12 & 1.15 & 1.14 & 0.62 & 0.75 & 0.82 & 1.74 & 1.89 & 1.96 \\
\hline & $\mathrm{Zn}$ & 1.25 & 1.21 & 1.21 & 0.76 & 0.79 & 0.92 & 1.94 & 1.99 & 2.13 \\
\hline & Mn & 1.17 & 1.18 & 1.21 & 0.70 & 0.77 & 0.88 & 1.92 & 1.96 & 2.09 \\
\hline & $\mathrm{Fe}+\mathrm{Zn}+\mathrm{Mn}$ & 1.30 & 1.37 & 1.24 & 0.78 & 0.80 & 0.93 & 2.08 & 2.18 & 2.17 \\
\hline \multicolumn{2}{|c|}{ Mean } & 1.17 & 1.20 & 1.19 & 0.69 & 0.76 & 0.87 & 1.86 & 1.96 & 2.06 \\
\hline \multirow{5}{*}{200} & Control & 1.22 & 1.45 & 1.43 & 0.82 & 1.08 & 1.24 & 2.03 & 2.54 & 2.67 \\
\hline & $\mathrm{Fe}$ & 1.38 & 1.47 & 1.45 & 0.83 & 1.12 & 1.27 & 2.21 & 2.59 & 2.71 \\
\hline & Zn & 1.43 & 1.49 & 1.49 & 0.93 & 1.20 & 1.27 & 2.35 & 2.69 & 2.76 \\
\hline & Mn & 1.36 & 1.49 & 1.46 & 0.92 & 1.13 & 1.27 & 2.29 & 2.62 & 2.73 \\
\hline & $\mathrm{Fe}+\mathrm{Zn}+\mathrm{Mn}$ & 1.49 & 1.53 & 1.50 & 1.01 & 1.23 & 1.34 & 2.50 & 2.77 & 2.83 \\
\hline \multicolumn{2}{|r|}{ Mean } & 1.38 & 1.49 & 1.47 & 0.90 & 1.15 & 1.28 & 2.28 & 2.64 & 2.74 \\
\hline \multirow{5}{*}{300} & Control & 1.07 & 1.33 & 1.24 & 0.70 & 0.86 & 0.98 & 1.76 & 2.19 & 2.22 \\
\hline & & 1.23 & 1.35 & 1.31 & 0.86 & 0.94 & 1.02 & 2.09 & 2.28 & 2.33 \\
\hline & $\mathrm{Zn}$ & 1.32 & 1.37 & 1.42 & 0.90 & 0.96 & 1.06 & 2.22 & 2.33 & 2.47 \\
\hline & Mn & 1.34 & 1.36 & 1.34 & 0.90 & 0.96 & 1.05 & 2.24 & 2.32 & 2.39 \\
\hline & $\mathrm{Fe}+\mathrm{Zn}+\mathrm{Mn}$ & 1.46 & 1.50 & 1.40 & 0.98 & 0.99 & 1.15 & 2.44 & 2.49 & 2.55 \\
\hline \multicolumn{2}{|c|}{ Mean } & 1.28 & 1.38 & 1.34 & 0.87 & 0.94 & 1.05 & 2.15 & 2.32 & 2.39 \\
\hline \multirow{5}{*}{\multicolumn{2}{|c|}{$\begin{array}{c}\text { Control } \\
\text { Fe } \\
\mathrm{Zn} \\
\mathrm{Mn} \\
\mathrm{Fe}+\mathrm{Zn}+\mathrm{Mn}\end{array}$}} & 1.10 & 1.30 & 1.27 & 0.71 & 0.87 & 1.01 & 1.81 & 2.17 & 2.27 \\
\hline & & 1.24 & 1.32 & 1.30 & 0.77 & 0.93 & 1.04 & 2.01 & 2.25 & 2.33 \\
\hline & & 1.33 & 1.36 & 1.37 & 0.86 & 0.98 & 1.08 & 2.17 & 2.34 & 2.45 \\
\hline & & 1.29 & 1.34 & 1.34 & 0.84 & 0.95 & 1.07 & 2.15 & 2.30 & 2.40 \\
\hline & & 1.42 & 1.47 & 1.38 & 0.92 & 1.01 & 1.14 & 2.34 & 2.48 & 2.52 \\
\hline \multirow{3}{*}{$\operatorname{LSD}_{0.05}$} & SA & 0.003 & 0.07 & 0.11 & 0.02 & 0.051 & 0.09 & 0.02 & 0.08 & 0.19 \\
\hline & Micro. & 0.01 & 0.04 & 0.05 & 0.03 & 0.032 & 0.02 & 0.03 & 0.07 & 0.06 \\
\hline & Interaction. & 0.002 & N.S & N.S & 0.06 & N.S & N.S & 0.06 & 0.06 & N.S \\
\hline
\end{tabular}

N.S indicate not significant at P: 0.05 .

\section{2- Bulb yield and its physical properties:}

Data presented in Table (8) indicated that culls yield $\left(\mathrm{t} \mathrm{fed}^{-1}\right)$, marketable yield $\left(\mathrm{t}\right.$ fed. $\left.{ }^{-1}\right)$, total yield of onion bulb ( $\mathrm{t}$ fed. $\left.{ }^{-1}\right)$, bulb weight (g) and bulb diameter $(\mathrm{cm})$ were significantly increased due to different treatments of salicylic acid. Application of $200 \mathrm{ppm}$ from salicylic acid gave the highest mean values of onion bulb yield and its physical properties in both seasons. The increase in yield of onion plants by using growth promoter (SA) might be due to enhancing assimilation nutrient uptake, nitrate reduction and photosynthesis, improved flow assimilates (translocation and cytoplasmic streaming) and increased cell integrity and in turn reflected on the increasing yield of onion plants. However, Abd El-Samad et al., 2011 indicated that foliar application of salicylic acid at the concentration of 200 ppm and 300 ppm increased 
yield of onion. These results are in agreement with those results obtained by Pradhan et al., 2016; Prajapati et al., (2016) and Shama et al. (2016).

Total bulbs yield as $t$ fed. ${ }^{-1}$, in both two experimental seasons as affected by foliar spraying of some micronutrients are shown in Table (8). Whereas, the bulbs yield recorded the maximum values with the application of micronutrients if compared with the control treatments. Moreover, the obtained data reveals that mixing ( $\mathrm{Fe}, \mathrm{Zn}$ and $\mathrm{Mn}$ ) as three elements together gained more yield and its component than plants, which received any one element as individually. This might be attributed to that plants, which sprayed by the three mixed elements resulted in best plant growth, which reflected on the onion bulb yield and its physical properties. The previous studies are in good accordance with that written here (Thapa et al., 2005; Sangeetha and singaram, 2007; Manna et al., 2014 and Manna and Maity, 2016). As reviewed above micronutrients are involved in many physiological processes, which seem to be positively affected by the application of Fe, $\mathrm{Zn}$ and $\mathrm{Mn}$. The increment in plant growth parameters may be brought about by the presence of the foliar spraying of the micronutrients which act as constituents of cell wall and membranes (Kirkby and Römheld, 2004). Finally, it could be summarized that, the heaviest bulbs yield were recorded when onion plants supplied micronutrients as mixing $\mathrm{Fe}+\mathrm{Zn}+\mathrm{Mn}$ together, followed in descending order by that plants received with $\mathrm{Zn}$ and/or $\mathrm{Mn}$. These findings are in good accordance during the two experimental seasons. On the contrary, onion plants which foliar sprayed with water (control) resulted in the lowest bulb yield as $t$ fed. ${ }^{-1}$ with the lowest culls yield. This was in line with the findings of Trivedi and Dhumal (2013) and Acharya et al. (2015a, b) in onion.

The interaction between foliar application with salicylic acid and micronutrients had a significant effect on onion bulb yield and its physical properties (Table, 8). Foliar application with $200 \mathrm{ppm}$ of salicylic acid with $2 \mathrm{ml} \mathrm{L}^{-1}$ of mixture from ( $\mathrm{Fe}, \mathrm{Zn}$ and $\mathrm{Mn}$ ) gave the heaviest bulb yield and the best values of bulb dimension and average weight in both seasons. The increase in bulb weight might be due to improving growth attributes as a result of positive influence of salicylic acid and micronutrients. Similar findings were also recorded by Pradhan et al., 2016 and Shama et al., 2016. The integrated nutrient management showed superior performance towards yield improvements (Thapa et al., 2005). The treatments of micronutrients along with salicylic acid might be responsible for increasing the chlorophyll content and there by photosynthetic rate, which usually cause increase in the yield. Manipulation of source (leaf) and sink 
(bulb) relationship through the above treatments may be the principal reason for yield improvement. This result was harmony with those reported by many authors Lee (2010) and Geries (2013).

Table (8): Effect of salicylic acid, micronutrients treatment and their interaction on bulb yield and its physical properties of onion in 2012/2013 and 2013/2014 seasons

\begin{tabular}{|c|c|c|c|c|c|c|c|c|c|c|c|}
\hline \multirow[b]{2}{*}{$\begin{array}{c}\text { Salicylic } \\
\text { acid }\end{array}$} & \multirow[b]{2}{*}{$\begin{array}{l}\text { Micro- } \\
\text { nutrient }\end{array}$} & \multicolumn{5}{|c|}{$2012 \backslash 2013$} & \multicolumn{5}{|c|}{$2013 \backslash 2014$} \\
\hline & & $\begin{array}{c}\text { Culls } \\
\text { yield } \\
\left.\text { (t fed. }{ }^{-1}\right)\end{array}$ & 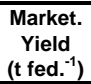 & $\begin{array}{c}\text { Total } \\
\text { yield } \\
\left(t \text { fed. } .^{-1}\right)\end{array}$ & $\begin{array}{c}\text { bulb } \\
\text { weight } \\
\text { (g) }\end{array}$ & $\begin{array}{c}\text { Bulb } \\
\text { diameter } \\
\text { (cm) }\end{array}$ & 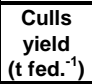 & $\begin{array}{c}\text { Market. } \\
\text { Yield } \\
\left.\text { (t fed. }{ }^{-1}\right)\end{array}$ & $\begin{array}{c}\text { Total } \\
\text { yield } \\
\left(t \text { fed. }{ }^{-1}\right)\end{array}$ & $\begin{array}{c}\text { bulb } \\
\text { weight } \\
\text { (g) }\end{array}$ & $\begin{array}{c}\text { Bulb } \\
\text { diameter } \\
(\mathrm{cm})\end{array}$ \\
\hline \multirow{5}{*}{100} & Control & 1.25 & 9.66 & 10.91 & 71.87 & 5.03 & 1.64 & 8.23 & 9.87 & 73.44 & 4.89 \\
\hline & $\mathrm{Fe}$ & 1.40 & 9.90 & 11.29 & 75.07 & 5.80 & 1.71 & 8.74 & 10.45 & 77.39 & 5.75 \\
\hline & $\mathrm{Zn}$ & 1.73 & 11.17 & 12.90 & 81.87 & 7.40 & 1.92 & 9.51 & 11.43 & 84.50 & 6.28 \\
\hline & Mn & 1.68 & 10.79 & 12.47 & 77.10 & 6.60 & 1.90 & 8.82 & 10.72 & 79.34 & 5.93 \\
\hline & $\mathrm{Fe}+\mathrm{Zn}+\mathrm{Mn}$ & 1.84 & 11.67 & 13.51 & 85.93 & 8.00 & 1.97 & 9.86 & 11.83 & 98.77 & 6.77 \\
\hline \multicolumn{2}{|c|}{ Mean } & 1.58 & 10.64 & 12.22 & 78.37 & 6.57 & 1.83 & 9.03 & 10.86 & 82.69 & 5.92 \\
\hline \multirow{5}{*}{200} & Control & 2.21 & 11.36 & 13.58 & 79.27 & 5.90 & 1.96 & 10.68 & 12.64 & 94.34 & 6.25 \\
\hline & $\mathrm{Fe}$ & 2.31 & 12.20 & 14.51 & 88.60 & 7.00 & 2.04 & 11.11 & 13.14 & 97.32 & 6.72 \\
\hline & Zn & 2.55 & 13.07 & 15.62 & 101.74 & 8.10 & 2.17 & 11.99 & 14.15 & 112.84 & 7.55 \\
\hline & Mn & 2.47 & 12.95 & 15.42 & 95.78 & 7.10 & 2.12 & 11.51 & 13.63 & 103.92 & 7.15 \\
\hline & $\mathrm{Fe}+\mathrm{Zn}+\mathrm{Mn}$ & 3.10 & 13.63 & 16.72 & 116.01 & 8.70 & 2.48 & 12.65 & 15.13 & 128.94 & 8.28 \\
\hline \multicolumn{2}{|c|}{ Mean } & 2.53 & 12.64 & 15.17 & 96.28 & 7.36 & 2.15 & 11.59 & 13.74 & 107.47 & 7.19 \\
\hline \multirow{5}{*}{300} & Control & 1.65 & 10.89 & 12.54 & 76.10 & 5.50 & 1.81 & 8.85 & 10.65 & 81.81 & 5.56 \\
\hline & $\mathrm{Fe}$ & 1.79 & 11.36 & 13.15 & 79.53 & 6.50 & 1.88 & 8.99 & 10.86 & 83.34 & 6.39 \\
\hline & $\mathrm{Zn}$ & 1.97 & 12.40 & 14.37 & 94.47 & 7.60 & 1.88 & 10.75 & 12.63 & 95.86 & 6.81 \\
\hline & Mn & 1.90 & 11.76 & 13.66 & 87.67 & 6.60 & 1.85 & 9.98 & 11.83 & 93.23 & 6.63 \\
\hline & $\mathrm{Fe}+\mathrm{Zn}+\mathrm{Mn}$ & 2.21 & 12.67 & 14.88 & 96.30 & 8.27 & 2.41 & 10.95 & 13.36 & 103.08 & 7.66 \\
\hline \multicolumn{2}{|r|}{ Mean } & 1.90 & 11.82 & 13.72 & 86.81 & 6.89 & 1.97 & 9.90 & 11.87 & 91.46 & 6.61 \\
\hline \multirow{5}{*}{\multicolumn{2}{|c|}{$\begin{array}{c}\text { Control } \\
\text { Fe } \\
\mathrm{Zn} \\
\mathrm{Mn} \\
\mathrm{Fe}+\mathrm{Zn}+\mathrm{Mn}\end{array}$}} & 1.70 & 10.64 & 12.34 & 75.75 & 5.48 & 1.80 & 9.25 & 11.05 & 83.19 & 5.57 \\
\hline & & 1.83 & 11.15 & 12.98 & 81.07 & 6.43 & 1.88 & 9.61 & 11.48 & 86.02 & 6.29 \\
\hline & & 2.08 & 12.21 & 14.30 & 92.69 & 7.70 & 1.99 & 10.75 & 12.74 & 97.73 & 6.88 \\
\hline & & 2.02 & 11.83 & 13.85 & 86.85 & 6.77 & 1.96 & 10.11 & 12.06 & 92.16 & 6.57 \\
\hline & & 2.38 & 12.66 & 15.04 & 99.41 & 8.32 & 2.29 & 11.14 & 13.44 & 110.26 & 7.57 \\
\hline \multirow{3}{*}{$\mathrm{LSD}_{0.05}$} & SA & 0.09 & 0.19 & 0.18 & 5.69 & 0.29 & 0.07 & 0.21 & 0.20 & 2.78 & 0.18 \\
\hline & Micro. & 0.13 & 0.19 & 0.26 & 3.72 & 0.22 & 0.08 & 0.19 & 0.21 & 3.03 & 0.13 \\
\hline & Interaction & N.S & 0.30 & 0.379 & N.S & N.S & 0.15 & 0.33 & 0.39 & 4.81 & N.S \\
\hline
\end{tabular}

N.S indicate not significant at P: 0.05 .

\section{3- Nutritional value of bulb tissues:}

Nutritional values of onion bulbs as affected by foliar application of salicylic acid and (Fe, $\mathrm{Zn}$ and $\mathrm{Mn}$ ) as individually and/or in mixture during the two experimental seasons are presented in Table (9). SA had significant effects on most parameters. Generally, the effect of 200 ppm SA was more pronounced than 100 and 300 ppm.

Whereas, spraying the three elements resulted an enhancement $\mathrm{N}, \mathrm{P}, \mathrm{K}, \mathrm{Fe}, \mathrm{Mn}$ and $\mathrm{Zn}$ content if compared with that onion plants had no received foliar nutritional elements (Table 9). Generally, it could be concluded, spraying $\mathrm{Zn}$ recorded the best nutritional values. Moreover, when mixing $\mathrm{Zn}$ with $\mathrm{Mn}$ and Fe together had more values of all nutritional values of compared with using $\mathrm{Fe}, \mathrm{Zn}$ and $\mathrm{Mn}$ alone. Shortly, it can conclude that, the best chemical constituent of onion bulbs were measured with that plant sprayed with 
mixing ( $\mathrm{Fe}, \mathrm{Zn}$ and $\mathrm{Mn}$ ). These results held good for all nutritional values of onion tissues during the two seasons. The highest nutritional values of onion bulb tissues which resulted with spraying plants with ( $\mathrm{Fe}, \mathrm{Zn}$ and $\mathrm{Mn}$ ) of both in combination might be attributed to the role of these elements in photosynthesis and metabolism processes which increased the plant growth, then increased the nutrient requirements, consequently their concentration in storage organ such onion bulb. The previous investigation showed that with the application of minerals as foliar caused an increase in the their uptakes (Shaheen et al., 2007; Abd El-Samad et al., 2011; Shaheen et al., 2012; Geries, 2013; Haque et al., 2014; Manna et al., 2014 and Manna and Maity, 2016).

The interaction of salicylic acid and micronutrients treatment had significant effect on all parameters in both seasons, Table (9). Generally, SA was more effective with plants sprayed with mixture of $\mathrm{Fe}, \mathrm{Zn}$ and Mn. However, the effect of medium level of SA was more pronounced, especially with the foliar application of $\mathrm{Fe}, \mathrm{Zn}$ and $\mathrm{Mn}$ together, but the poorest quality was detected with $100 \mathrm{ppm}$ of SA and foliar nutritional with water (control plants).

\section{4- Cumulative weight loss of onion bulb during storage:}

The percentage of weight loss of onion bulbs and reminder of onion bulbs at different periods of storage was significantly influenced by foliar spraying of salicylic acid and (Fe, $\mathrm{Zn}$ and $\mathrm{Mn}$ ) as individually and/or in mixture during the two seasons (Table 10). SA had significant effects on total weight loss and reminder of onion bulbs. The effect of 200 ppm SA was more pronounced than 300 and 100 $\mathrm{ppm}$. The weight loss progressively increased with increased storage period. SA treatment decreased weight loss of bulbs at all concentrations. The reduction in weight loss due to foliar spraying by $\mathrm{SA}$ at the rate $200 \mathrm{ppm}$ during growth season of onion which resulted in bulbs with high quality can tolerate the storing for long periods. Similar result was also reported by Prajapati et al. (2016).

Application of $\mathrm{Fe}, \mathrm{Zn}$ and $\mathrm{Mn}$ as individually and/or in mixture caused highly significant variation in terms of total weight loss and reminder of onion bulbs. The minimum total weight loss at the end of storage period was produced by the treatment $2 \mathrm{ml} \mathrm{L}^{-1}$ of Fe, $\mathrm{Zn}$ and $\mathrm{Mn}$ as mixed together and that had lead to significantly highest reminder of onion bulbs percent $(69.28$ and $78.94 \%$ in the two seasons, respectively). The results on the effects of micronutrients treatment on the storability of onion plants agreed with the results obtained by Manna et al. (2014) and Obiadalla-Ali et al. (2016) who 
indicated that application of micronutrients increased onion bulb storability by reducing total weight loss

Table (9): Contents of some macro and micro nutrients in onion bulb tissues as influenced by salicylic acid and micronutrients treatment during 2012/2013 and 2013/2014 seasons

\begin{tabular}{|c|c|c|c|c|c|c|c|}
\hline \multirow{3}{*}{$\begin{array}{l}\text { Salicylic } \\
\text { acid }\end{array}$} & \multirow{3}{*}{ Micronutrient } & \multicolumn{6}{|c|}{$2012 \backslash 2013$} \\
\hline & & $\mathbf{N}$ & $\mathbf{P}$ & $\mathrm{K}$ & $\mathrm{Fe}$ & Mn & Zn \\
\hline & & \multicolumn{3}{|c|}{$\%$} & \multicolumn{3}{|c|}{ ppm } \\
\hline 100 & $\begin{array}{c}\text { Control } \\
\mathrm{Fe} \\
\mathrm{Zn} \\
\mathrm{Mn} \\
\mathrm{Fe}+\mathrm{Zn}+\mathrm{Mn}\end{array}$ & $\begin{array}{l}1.41 \\
1.42 \\
1.46 \\
1.52 \\
1.57\end{array}$ & $\begin{array}{l}0.25 \\
0.26 \\
0.27 \\
0.27 \\
0.29\end{array}$ & $\begin{array}{l}0.52 \\
0.52 \\
0.54 \\
0.51 \\
0.54\end{array}$ & $\begin{array}{l}261.36 \\
270.56 \\
256.18 \\
262.67 \\
271.34\end{array}$ & $\begin{array}{l}34.08 \\
35.51 \\
35.75 \\
35.97 \\
37.41\end{array}$ & $\begin{array}{l}35.60 \\
30.83 \\
31.67 \\
31.20 \\
33.20\end{array}$ \\
\hline \multicolumn{2}{|c|}{ Mean } & 1.48 & 0.27 & 0.53 & 264.42 & 35.74 & 32.50 \\
\hline 200 & $\begin{array}{c}\text { Control } \\
\mathrm{Fe} \\
\mathrm{Zn} \\
\mathrm{Mn} \\
\mathrm{Fe}+\mathrm{Zn}+\mathrm{Mn}\end{array}$ & $\begin{array}{l}1.51 \\
1.47 \\
1.49 \\
1.56 \\
1.57\end{array}$ & $\begin{array}{l}0.28 \\
0.29 \\
0.30 \\
0.30 \\
0.31\end{array}$ & $\begin{array}{l}0.53 \\
0.58 \\
0.55 \\
0.57 \\
0.60\end{array}$ & $\begin{array}{l}283.25 \\
302.50 \\
299.10 \\
292.01 \\
306.47\end{array}$ & $\begin{array}{l}57.65 \\
59.33 \\
58.44 \\
59.57 \\
60.12\end{array}$ & $\begin{array}{l}42.70 \\
43.28 \\
44.15 \\
43.71 \\
43.60\end{array}$ \\
\hline \multicolumn{2}{|c|}{ Mean } & 1.52 & 0.29 & 0.57 & 296.67 & 59.02 & 43.49 \\
\hline 300 & $\begin{array}{c}\text { Control } \\
\mathrm{Fe} \\
\mathrm{Zn} \\
\mathrm{Mn} \\
\mathrm{Fe}+\mathrm{Zn}+\mathrm{Mn}\end{array}$ & $\begin{array}{l}1.48 \\
1.57 \\
1.61 \\
1.54 \\
1.64\end{array}$ & $\begin{array}{l}0.30 \\
0.30 \\
0.31 \\
0.31 \\
0.32\end{array}$ & $\begin{array}{l}0.57 \\
0.56 \\
0.59 \\
0.59 \\
0.60\end{array}$ & $\begin{array}{l}267.71 \\
288.25 \\
287.58 \\
276.10 \\
296.20\end{array}$ & $\begin{array}{l}41.85 \\
42.20 \\
43.10 \\
42.85 \\
44.79\end{array}$ & $\begin{array}{l}36.91 \\
37.21 \\
39.09 \\
37.27 \\
40.44\end{array}$ \\
\hline \multicolumn{2}{|c|}{ Mean } & 1.57 & 0.31 & 0.59 & 283.17 & 42.96 & 38.18 \\
\hline \multicolumn{2}{|c|}{$\begin{array}{c}\text { Control } \\
\text { Fe } \\
\mathrm{Zn} \\
\mathrm{Mn} \\
\mathrm{Fe}+\mathrm{Zn}+\mathrm{Mn}\end{array}$} & $\begin{array}{l}1.47 \\
1.49 \\
1.52 \\
1.54 \\
1.59\end{array}$ & $\begin{array}{l}0.28 \\
0.28 \\
0.29 \\
0.29 \\
0.31\end{array}$ & $\begin{array}{l}0.54 \\
0.55 \\
0.56 \\
0.56 \\
0.58\end{array}$ & $\begin{array}{l}270.77 \\
287.10 \\
280.95 \\
276.93 \\
291.34\end{array}$ & $\begin{array}{l}44.52 \\
45.68 \\
45.76 \\
46.13 \\
47.44\end{array}$ & $\begin{array}{l}36.40 \\
37.11 \\
38.30 \\
37.39 \\
39.08\end{array}$ \\
\hline \multirow{3}{*}{$\operatorname{LSD}_{0.05}$} & SA & 0.05 & 0.03 & 0.017 & 2.73 & 1.43 & 1.52 \\
\hline & Micro. & 0.06 & N.S & 0.01 & 3.95 & 1.62 & N.S \\
\hline & Interaction & N.S & N.S & 2.33 & 6.84 & N.S & N.S \\
\hline \multicolumn{8}{|c|}{$2013 \backslash 2014$} \\
\hline \multirow{2}{*}{\multicolumn{2}{|c|}{$\frac{\mathrm{Fe}+\mathrm{Zn}+\mathrm{Mn}}{\text { Mean }}$}} & $\begin{array}{l}1.54 \\
1.51 \\
1.42 \\
1.46 \\
1.52\end{array}$ & $\begin{array}{l}0.27 \\
0.27 \\
0.28 \\
0.28 \\
0.28\end{array}$ & $\begin{array}{l}0.52 \\
0.53 \\
0.54 \\
0.54 \\
0.55\end{array}$ & $\begin{array}{l}244.16 \\
256.14 \\
253.12 \\
249.91 \\
257.79\end{array}$ & $\begin{array}{l}35.21 \\
35.52 \\
36.25 \\
36.16 \\
36.39\end{array}$ & $\begin{array}{l}35.63 \\
36.17 \\
36.42 \\
36.26 \\
36.78\end{array}$ \\
\hline & & 1.49 & 0.28 & 0.54 & 252.22 & 35.90 & 36.25 \\
\hline 200 & $\begin{array}{c}\text { Control } \\
\mathrm{Fe} \\
\mathrm{Zn} \\
\mathrm{Mn} \\
\mathrm{Fe}+\mathrm{Zn}+\mathrm{Mn}\end{array}$ & $\begin{array}{l}1.57 \\
1.47 \\
1.51 \\
1.49 \\
1.56\end{array}$ & $\begin{array}{l}0.29 \\
0.29 \\
0.30 \\
0.29 \\
0.30\end{array}$ & $\begin{array}{l}0.55 \\
0.56 \\
0.57 \\
0.56 \\
0.57\end{array}$ & $\begin{array}{l}270.53 \\
278.17 \\
275.42 \\
276.71 \\
288.55\end{array}$ & $\begin{array}{l}44.44 \\
44.62 \\
44.93 \\
45.22 \\
45.40\end{array}$ & $\begin{array}{l}38.39 \\
38.61 \\
39.27 \\
38.84 \\
39.43\end{array}$ \\
\hline \multicolumn{2}{|c|}{ Mean } & 1.52 & 0.29 & 0.56 & 277.88 & 44.92 & 38.91 \\
\hline 300 & $\begin{array}{c}\text { Control } \\
\mathrm{Fe} \\
\mathrm{Zn} \\
\mathrm{Mn} \\
\mathrm{Fe}+\mathrm{Zn}+\mathrm{Mn}\end{array}$ & $\begin{array}{l}1.47 \\
1.59 \\
1.60 \\
1.59 \\
1.56\end{array}$ & $\begin{array}{l}0.26 \\
0.32 \\
0.30 \\
0.30 \\
0.31\end{array}$ & $\begin{array}{l}0.57 \\
0.58 \\
0.59 \\
0.58 \\
0.60\end{array}$ & $\begin{array}{l}258.51 \\
266.88 \\
264.30 \\
261.18 \\
266.58\end{array}$ & $\begin{array}{l}39.84 \\
40.08 \\
40.64 \\
41.03 \\
41.21\end{array}$ & $\begin{array}{l}37.69 \\
37.97 \\
38.15 \\
38.01 \\
38.25\end{array}$ \\
\hline \multicolumn{2}{|c|}{ Mean } & 1.56 & 0.30 & 0.58 & 263.49 & 40.56 & 38.01 \\
\hline \multicolumn{2}{|c|}{$\begin{array}{c}\text { Control } \\
\text { Fe } \\
\mathrm{Zn} \\
\mathrm{Mn} \\
\mathrm{Fe}+\mathrm{Zn}+\mathrm{Mn}\end{array}$} & $\begin{array}{l}1.52 \\
1.52 \\
1.51 \\
1.51 \\
1.55\end{array}$ & $\begin{array}{l}0.27 \\
0.29 \\
0.29 \\
0.29 \\
0.29\end{array}$ & $\begin{array}{l}0.55 \\
0.56 \\
0.57 \\
0.56 \\
0.57\end{array}$ & $\begin{array}{l}257.73 \\
267.06 \\
264.28 \\
262.60 \\
270.97\end{array}$ & $\begin{array}{l}39.83 \\
40.07 \\
40.61 \\
40.80 \\
41.00\end{array}$ & $\begin{array}{l}37.24 \\
37.58 \\
37.95 \\
37.70 \\
38.15\end{array}$ \\
\hline \multirow{3}{*}{$\operatorname{LSD}_{0.05}$} & SA & N.S & N.S & 0.032 & 8.03 & 2.45 & 1.71 \\
\hline & Micro. & N.S & 0.023 & 0.008 & 7.75 & N.S & 0.19 \\
\hline & Interaction & N.S & N.S & N.S & N.S & N.S & N.S \\
\hline
\end{tabular}

N.S indicate not significant at P: 0.05 .

Data presented in Table (10) indicated that the storability of onion significantly increased due to the interaction between different treatment of salicylic acid and micronutrients. The highest values of 
weight loss percent were obtained with SA at $100 \mathrm{ppm}$ and foliar spraying with water at the end of the storage period. The lowest percent of total weight loss were 6.06, 6.83, 11.81 and 3.83, 5.74 and $8.61 \%$ at $200 \mathrm{ppm}$ of SA and foliar spraying with Fe, Zn and Mn together, at different days after storage in both seasons, respectively.

\section{Economic analysis:}

Data presented in Figures (1, 2 and 3) indicated that, spraying onion plants with salicylic acid at $200 \mathrm{ppm}$ with micronutrients Fe, Mn and $\mathrm{Zn}$ at the rate of $2 \mathrm{ml} \mathrm{L}^{-1}$ resulted the highest gross return (19110 L.E.) which gave net return of 10330 L.E fed. ${ }^{-1}$ with the highest of benefit: cost ratio of onion yield (2.18). Total yield was increased as overall mean values through the two growing seasons about $2.82 \mathrm{t} \mathrm{fed}^{-1}$ under combination of salicylic acid at 200 ppm with mixture of $\mathrm{Fe}, \mathrm{Zn}$ and $\mathrm{Mn}$ over the control treatment (spraying with water) with salicylic acid at 200 ppm (as showed in Table, 8).

Table (10): Total weight loss and remained bulbs\% of onion bulbs during storage as affected by salicylic acid and micronutrients treatment during 2012/2013 and 2013/2014 seasons

\begin{tabular}{|c|c|c|c|c|c|c|c|c|c|}
\hline \multirow{4}{*}{ SA } & \multirow{4}{*}{ Micro. } & \multicolumn{4}{|c|}{$2012 \backslash 2013$} & \multicolumn{4}{|c|}{$2013 \backslash 2014$} \\
\hline & & \multicolumn{8}{|c|}{ Storage period (Day) } \\
\hline & & \multicolumn{3}{|c|}{ Total weight loss (\%) } & \multirow{2}{*}{$\begin{array}{c}\text { Remained } \\
\text { bulbs } \%\end{array}$} & \multicolumn{3}{|c|}{ Total weight loss (\%) } & \multirow{2}{*}{$\begin{array}{l}\text { Remained } \\
\text { bulbs } \%\end{array}$} \\
\hline & & 60 & 120 & 180 & & 60 & 120 & 180 & \\
\hline \multirow{5}{*}{100} & Control & 14.75 & 11.95 & 17.44 & 55.86 & 10.90 & 15.10 & 25.03 & 48.97 \\
\hline & $\mathrm{Fe}$ & 14.59 & 11.21 & 16.29 & 57.91 & 6.79 & 12.55 & 23.72 & 56.94 \\
\hline & $\mathbf{Z n}$ & 13.19 & 10.42 & 16.25 & 60.14 & 5.56 & 8.92 & 18.60 & 66.93 \\
\hline & Mn & 11.36 & 9.77 & 16.00 & 62.87 & 4.85 & 8.00 & 16.81 & 70.34 \\
\hline & $\mathrm{Fe}+\mathrm{Zn}+\mathrm{Mn}$ & 10.47 & 9.96 & 15.83 & 63.74 & 4.46 & 6.84 & 11.24 & 77.47 \\
\hline \multicolumn{2}{|c|}{ Mean } & 12.87 & 10.66 & 16.36 & 60.10 & 6.51 & 10.28 & 19.08 & 64.13 \\
\hline \multirow{5}{*}{200} & Control & 8.36 & 9.54 & 15.05 & 67.06 & 7.53 & 9.33 & 26.01 & 57.14 \\
\hline & $\mathrm{Fe}$ & 7.24 & 9.11 & 13.94 & 69.71 & 5.57 & 8.65 & 18.97 & 66.82 \\
\hline & $\mathrm{Zn}$ & 6.81 & 8.25 & 13.15 & 71.79 & 5.28 & 8.21 & 16.47 & 70.04 \\
\hline & Mn & 6.60 & 7.43 & 12.22 & 73.74 & 4.26 & 7.20 & 13.60 & 74.95 \\
\hline & $\mathrm{Fe}+\mathrm{Zn}+\mathrm{Mn}$ & 6.06 & 6.83 & 11.81 & 75.30 & 3.83 & 5.74 & 8.61 & 81.83 \\
\hline \multicolumn{2}{|c|}{ Mean } & 7.01 & 8.23 & 13.23 & 71.52 & 5.29 & 7.82 & 16.73 & 70.16 \\
\hline \multirow{5}{*}{300} & Control & 10.25 & 10.57 & 15.63 & 63.56 & 10.39 & 12.13 & 27.17 & 50.31 \\
\hline & $\mathrm{Fe}$ & 9.53 & 9.50 & 15.19 & 65.78 & 5.71 & 10.82 & 16.12 & 67.36 \\
\hline & $\mathrm{Zn}$ & 8.35 & 9.37 & 14.89 & 67.40 & 6.54 & 8.62 & 15.89 & 68.96 \\
\hline & Mn & 7.31 & 8.59 & 13.62 & 70.48 & 4.71 & 7.77 & 15.03 & 72.49 \\
\hline & $\mathrm{Fe}+\mathrm{Zn}+\mathrm{Mn}$ & 6.43 & 8.22 & 16.56 & 68.79 & 4.37 & 6.41 & 11.70 & 77.52 \\
\hline \multicolumn{2}{|c|}{ Mean } & 8.37 & 9.25 & 15.18 & 67.20 & 6.34 & 9.15 & 17.18 & 67.33 \\
\hline \multirow{4}{*}{\multicolumn{2}{|c|}{$\begin{array}{c}\text { Control } \\
\text { Fe } \\
\mathrm{Zn} \\
\mathrm{Mn}\end{array}$}} & 11.12 & 10.69 & 16.04 & 62.16 & 9.61 & 12.19 & 26.07 & 52.14 \\
\hline & & 10.45 & 9.94 & 15.14 & 64.47 & 6.02 & 10.67 & 19.60 & 63.71 \\
\hline & & 9.45 & 9.35 & 14.76 & 66.44 & 5.79 & 8.58 & 16.99 & 68.64 \\
\hline & & 8.42 & 8.60 & 13.95 & 69.03 & 4.60 & 7.66 & 15.14 & 72.60 \\
\hline \multicolumn{2}{|c|}{$\mathrm{Fe}+\mathrm{Zn}+\mathrm{Mn}$} & 7.65 & 8.34 & 14.73 & 69.28 & 4.22 & 6.33 & 10.52 & 78.94 \\
\hline \multirow{3}{*}{$\operatorname{LSD}_{0.05}$} & SA & 0.36 & 0.18 & 0.61 & 0.65 & 0.41 & 0.65 & 1.202 & 1.480 \\
\hline & Micro. & 0.29 & 0.35 & 0.71 & 1.01 & 0.51 & 0.65 & 1.43 & 1.87 \\
\hline & Interaction & 0.50 & N.S & N.S & N.S & 0.879 & 1.13 & 2.48 & 3.24 \\
\hline
\end{tabular}

N.S indicate not significant at P: 0.05 . 


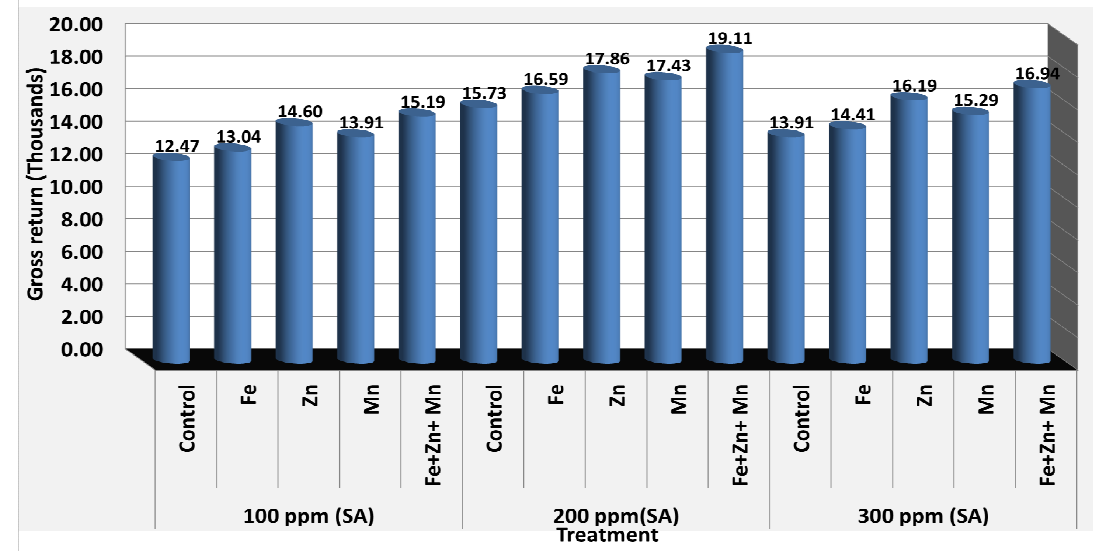

Figure 1: Gross returns (L.E. fed. ${ }^{-1}$ ) of onion yield as influenced by salicylic acid and micronutrients treatment as overall mean values through the two growing seasons

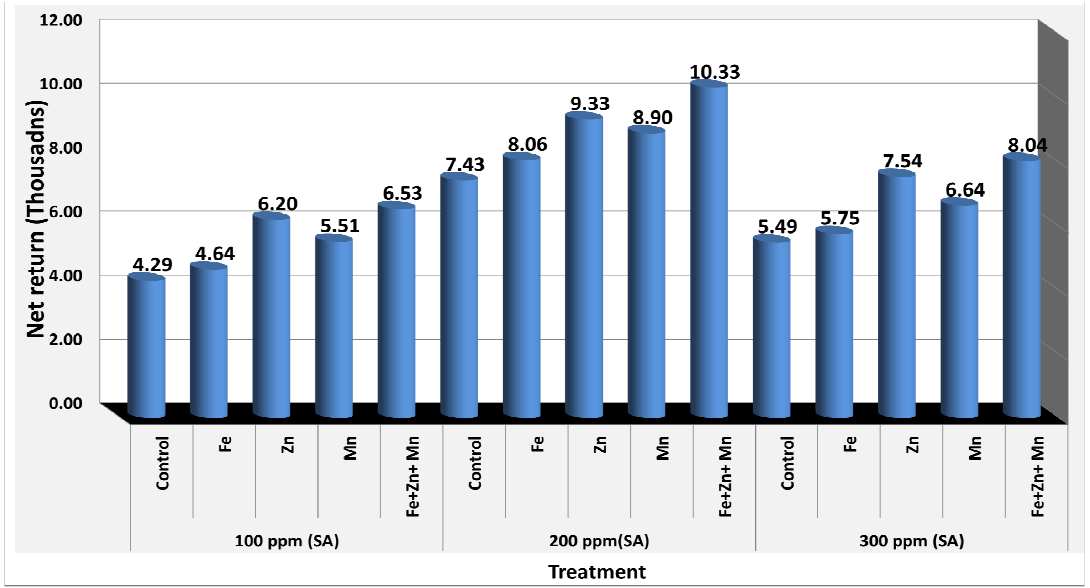

Figure 2: Net returns (L.E. fed. ${ }^{-1}$ ) of onion yield as affected by salicylic acid and micronutrients treatment as overall mean values through the two growing seasons

On the other hand, mixing of salicylic acid at 100 ppm and spraying with water treatment (control) gave the lowest values of gross return, net return and benefit: cost ratio (12470, 4290 L.E fed. ${ }^{-1}$ and $1.52 \%$, respectively).

From the economic point of view, it can be concluded that salicylic acid and the combination $\mathrm{Fe}+\mathrm{Zn}+\mathrm{Mn}$ as foliar spray had 
remarkable effects and increased bulb weight and bulb yield of onion bulbs with the best benefit: cost ratio in both seasons.

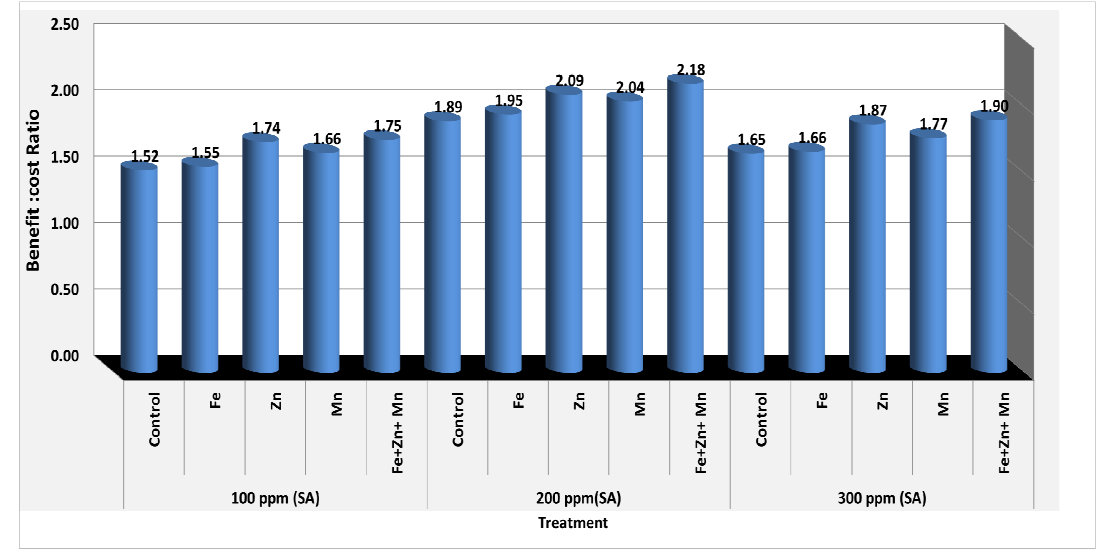

Figure 3: Benefit: cost ratio of onion yield as influenced by salicylic acid and micronutrients treatment as overall mean values through the two growing seasons

\section{REFERENCES}

Abd El-Samad, E. H.; R. Kh. M. Khalifa; Z. A. Lashine and M. R. Shafeek (2011). Influence of urea fertilization and foliar application of some micronutrients on growth, yield and bulb quality of onion. Australian Journal of Basic and Applied Sciences, 5(5): 96-103.

Abdissa, Y.; T. Tekalign and L. M. Pant (2011). Growth, bulb yield and quality of onion (Allium cepa L.) as influenced by nitrogen and phosphorus fertilization on vertisol. I. growth attributes, biomass production and bulb yield. African Journal of Agricultural Research 6 (14): 3252-3258.

Acharya, U.; K. Venkatesan; T. Saraswathi and K. S. Subramanian (2015a). Physiological and yield parameters of multiplier onion (Allium cepa, L. var aggregatum Don.) Var. $\mathrm{CO}(\mathrm{On}) 5$ as influenced by zinc and boron application. HortFlora Research Spectrum, 4(2): 155-158.

Acharya, U.; K. Venkatesan; T. Saraswathi and K.S.Subramanian (2015b). Effect of zinc and boron application on growth and yield parameters of multiplier onion (Allium cepa L. var aggregatum Don.) var. CO (On)5. International Journal of Research 2(1): 757765.

Aisha, H.A.; Fatma, A. Rizk, A.M. Shaheen and Mona M. Abdel-Mouty (2007). Onion plant growth, bulbs yield and its physical and chemical properties as affected by organic and natural fertilization. Res. J. Agric. Bio. Sci., 3(5): 380 -388. 
Amin, A. A.; EL-Sh. M. Rashad and H.M.H. EL-Abagy (2007). Physiological effect of indole - 3 - butyric acid and salicylic acid on growth, yield and chemical constituents of onion plants. J. of Applied Sci. Res., 3(11): 1554-1563.

Ballabh, K.; D. K. Rana and S. S. Rawat (2014). Effects of foliar application of micronutrients on growth, yield and quality of onion. Indian Journal of Horticulture, 70(2):260-265.

Brown, J. D. and O. Lilleland (1946). Rapid determination of potassium and sodium in plant material and soil extracts by flame photometry. Proc. Amer. Soc. Hort. Sci., 48: 341-346.

Carr, J.P., M.G.Lewsey and P.Palukaitis (2010). Signaling in induced resistance. Advances in Virus. Research, 76, 57-121.

Chapman, H. D. and P. F. Pratt (1978). Methods of Analysis for Soils, Plants and Waters. Univ. California, Div.Agric. Sci., Priced Pub. 4034.

Corcoles, J. I., A. Domínguez, M.A. Moreno, J.F. Ortega and J.A. de Juan (2015). A non-destructive method for estimating onion leaf area. Irish J. Agric. Food Res., 54 (1): 17-30. (doi: 10.1515/ijafr-2015-0002 IJAFR).

Dake, S. D.; B. G. Hiwale; V. K. Patil and P. G. Naik (2011). Effect of micronutrients on growth, yield and quality of onion (Allium cepa, L.) cv. Baswant 780. National symposium on Alliums: current Scenario and Emerging Trends, 12-14 March, 2011,Pune. pp-205.

Gamelli, E. L. and Hanna, E. L. Hadi (2000). The effect of some foliar fertilizers application on growth, bulb yield, quality and storage ability of Giza 20 onion cultivar (Allium capa, L). Annals of Agril. Sci. Moshtohor, 38 (3): 1727-1737.

Geries, L. S. M. (2013). Effect of nitrogen fertilizer and foliar spraying with humic acid on growth and yield of onion (Allium cepa, L.). Egypt. J. of Appl. Sci., 28 (4): 204-226.

Gomez, K. N. and A. A. Gomez (1984). Statistical procedures for agricultural research. John Wiley and Sons, New York, 2nd Ed., 68 P.

Haggag, Wafaa, M. and M. Saber (2007). Suppression of Alternaria blighton tomato and onion by foliar spray of aerated and nonaerated compost teas. Journal of Food, Agriculture and Environment (Finland), 5(2): 302-309.

Haque R.; M. Robbani; M. Hasan, M. Hasan and J. A. Teixeira da Silva (2014). Zinc and boron affect yield and quality of onion (Allium cepa,L.) seed. International Journal of Vegetable Science, 20(2):131-140.

Khan, A. A.; M. Zubair; A. Bari and F. Maula (2007). Response of onion (allium cepa, L.) growth and yield to different levels of nitrogen and zinc in swat valley. Sarhad Journal of Agriculture, 23(4): 933936. 
Kirkby, E. A. and V. Römheld (2004). Micronutrients in plant physiology: functions, uptake and mobility. Proceedings No. 543, International Fertiliser Society.

Lee, J. (2010). Effect of application methods of organic fertilizer on growth, soil chemical properties and microbial densities in organic bulb onion production. Scientia Horticulturae, 124 (2010): 299-305

Malik, M. N. (1994). Bulb crops, onion. In. Horticulture. National Book Foundation Islamabad Pakistan.pp. 500- 01.

Manna, D. and T. K. Maity (2016). Growth, yield and bulb quality of onion (Allium cepa, L.) in response to foliar application of boron and zinc. Journal of Plant Nutrition Journal,39 (3):438-441.

Manna, D.; T. K. Maity and A. Ghosal (2014). Influence of foliar application of boron and zinc on growth, yield and bulb quality of onion (Allium cepa, L.). Journal of Crop and Weed, 10(1):53-55.

Mishra, P.; C. Sarkar; K. P. Viswajith; B. S. Dhekale and P. K. Sahu (2013). Instability and forecasting using ARIMA model in aua, Production and productivity of onion in India, J. Crop Weed, 9:9601

Obiadalla-Ali, H. A.; K. A. A. El-Shaikh and Z. Sedra Amal (2016). Effect of foliar application with trace elements, potassium fertilization and storage methods on storability of three onion (Allium cepa, L.) cultivars. American-Eurasian J. Agric. \& Environ. Sci., 16 (7): 13041320.

Page, A. L. (1982). Methods of Soil Analysis. 2nd Ed., Part 1, Soil Sci.Soc.Amer. Madisci, Wise., USA.

Pradhan, M.; P. Tripathy; P. Mandal; B. B. Sahoo; R. Pradhan; S. P. Mishra and H. N. Mishra (2016). Effect of salicylic acid on growth and bulb yield of onion (Allium Cepa, L.). International Journal of Bio-resource and Stress Management, 7(4):960-963.

Prajapati, S.; P. K. Jain and T. Akhilesh (2016). Effects of Salicylic acid (SA) and Azospirillum on growth andbulb yield of Onion (Allium cepa L.) cv. Agrifound Light Red. International Journal of Agriculture, Environment and Biotechnology, 9(3): 393-402

Pregl, F. (1945). "Guntitative organic micro - analysis " 1 " Ed.J.and A.Churdill, Itd.London.

Sangeetha, M. and P. Singaram (2007). Effect of lignite humic acid and inorganic fertilizers on growth and yield of onion. The Asian J. of Soil Sci., 2(1): 108-110.

Shaheen, A. M.; Fatma A. Rizk and S. M. Singer (2007). Growing onion plants without chemical fertilization. Research J. Agric. Bio., Sci., 3(2): 95 - 104.

Shaheen, A. M.; Fatma A. Rizk, A. M. M. El- Tanahy and E. H. abd ElSamad (2012). Vegetative growth and chemical parameters of onion as influenced by potassium as major and stimufol as minor fertilizers. Australian J. of Basic and Applied Sciences, 5(11):518525. 
Shama, M. A.; S. A. M. Moussa; Nashwa I. Abo El Fadel (2016). Salicylic acid efficacy on resistance of garlic plants (Allium sativum, L.) to water salinity stress on growth, yield and its quality. Alexandria Sci., Exchange J., 37(2):165-174.

Thapa, U. M. K. Patti; S. R. Chattopadhyay and A. R. Mandal (2005). Growth and seed yield of onion (Allium Cepa, L.) cv. Sukh sagar as influenced by growth regulators and bulb size. Research on crops, 6(1): 55-57.

Trivedi A. P. and K. N. Dhumal (2013). Effect of soil and foliar applications of zinc and iron on the yield and quality of onion (Allium cepa L.). Bangladesh J. Agril. Res., 38(1): 41-48.

Troug, E. and A. H. Mayer (1939). Improvement in the dewiness calorimetric method for phosphorus and arsenic Indian. Engineering chemical Annuals Ed., 1: 136-139.

Wettesteien, D. (1957). Chlorophyll, Letal and der submicroskopische. Formmech Sell der Platiden. Exptl. Cell. Res., 12: 427-433.

Wills, R. H.; T. H. Lee; D. Gerham; W. B. Mc-Gllasson and E. G. Hall (1982). Postharvest and introduction to physiology and handling of fruit and vegetable. The AVF Publishing Comp. Inc. Westport. Conn. PP. 35.

$$
\text { الملخص العربى }
$$

تأثير الرش الورقي بحمض السالسليك وبعض العناصر الصغرى على نمو ومحصول وجودة البصل

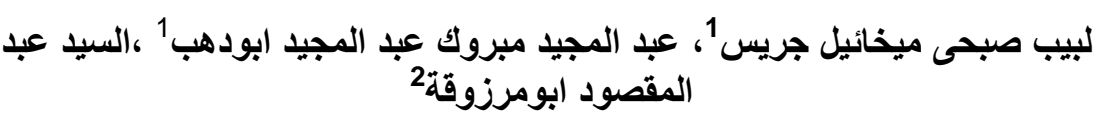

1قسم بحوث البصل - معهد بحوث المحاصيل الحقلية - مركز البردوف البحوث الزراعية ـ الجيزة- مصر.

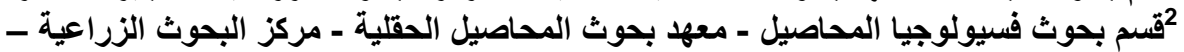

$$
\text { الجيزة- مصر. }
$$

أجريت تجربتان حقلينان خلال الموسمين 2012/ 2013 و 2014/2013م

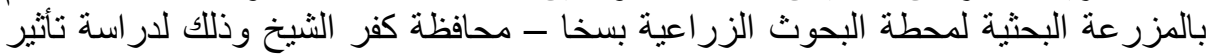

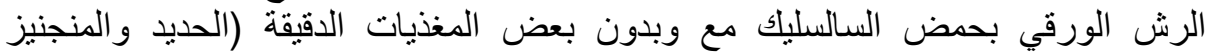
و الزنلك)، وكذلك تفاعلها، على النمو ومحصول البصل ودون وعلى القدرة الإنتاجية والتخزينية

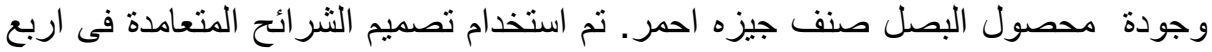

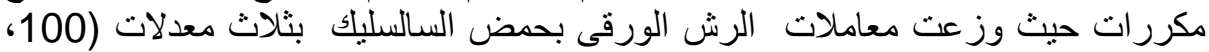

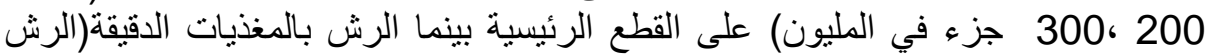

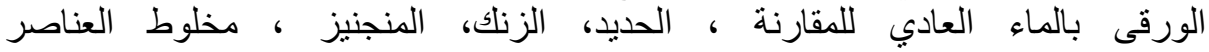

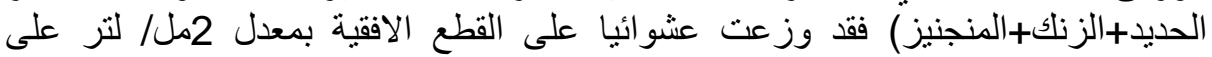

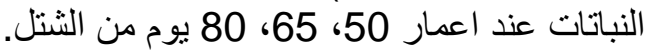




\section{ويمكن تلخيص أهم النتائج فيما يلى:}

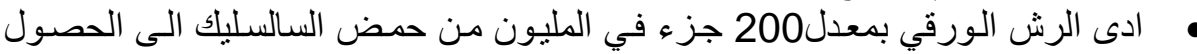

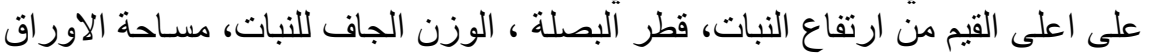

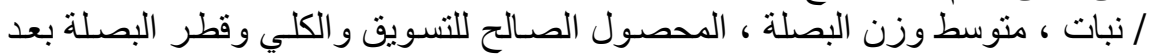

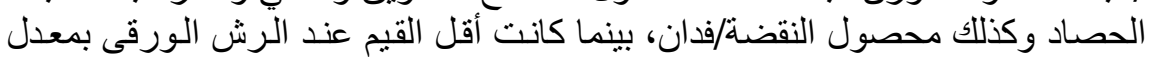
100 جزء فى المليون من حمض الس السالسليك.

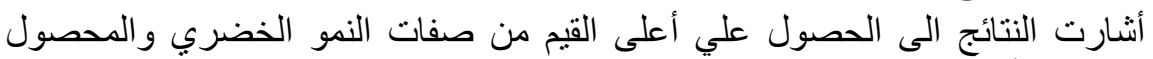

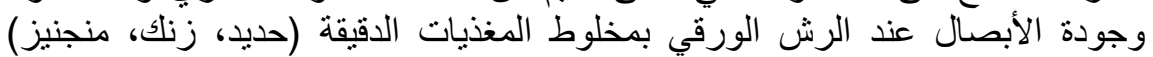

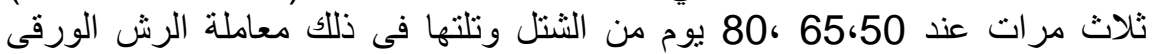
بالزنك منفردا وذلك في كلا الموسمين.

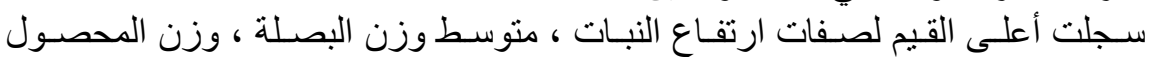

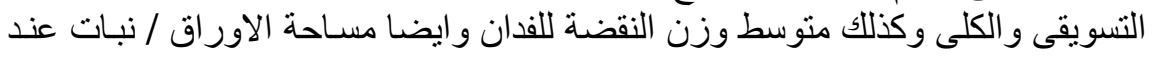

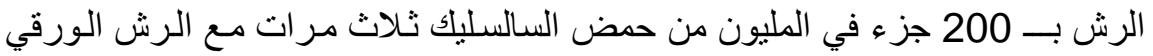

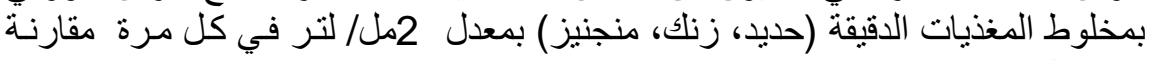

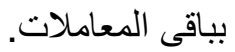

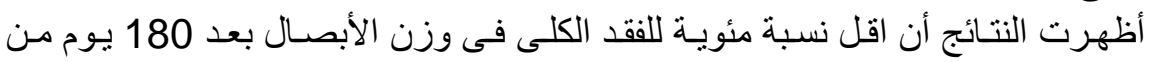

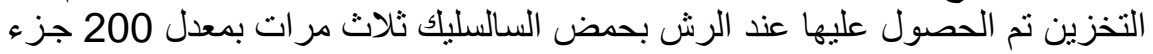

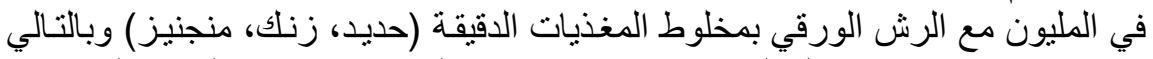

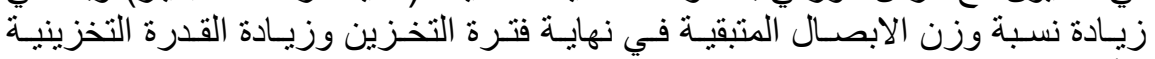

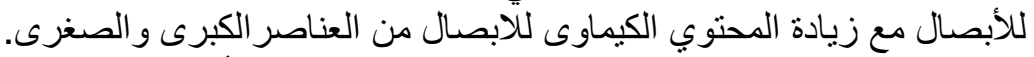

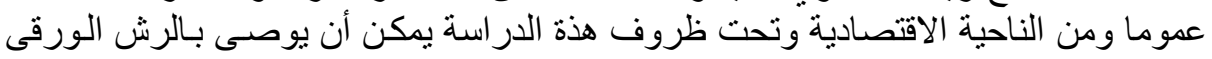

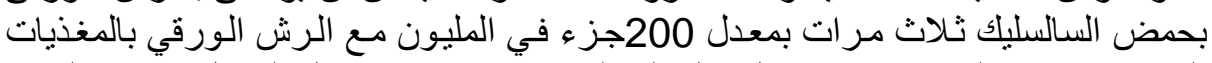

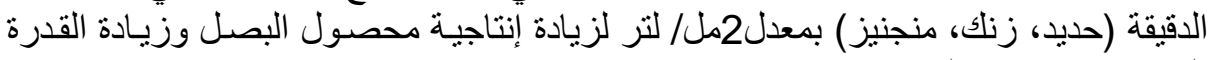

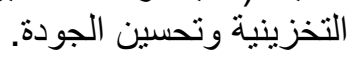

